\title{
Ecological and functional consequences of coastal ocean acidification: Perspectives from the Baltic-Skagerrak System
}

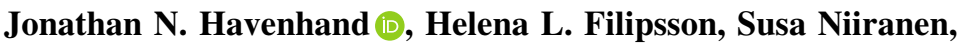 \\ Max Troell, Anne-Sophie Crépin, Sverker Jagers, David Langlet, \\ Simon Matti, David Turner, Monika Winder, Pierre de Wit, \\ Leif G. Anderson
}

Received: 31 October 2017/Revised: 21 May 2018/Accepted: 3 October 2018/Published online: 1 December 2018

\begin{abstract}
Ocean temperatures are rising; species are shifting poleward, and $\mathrm{pH}$ is falling (ocean acidification, $\mathrm{OA})$. We summarise current understanding of $\mathrm{OA}$ in the brackish Baltic-Skagerrak System, focussing on the direct, indirect and interactive effects of $\mathrm{OA}$ with other anthropogenic drivers on marine biogeochemistry, organisms and ecosystems. Substantial recent advances reveal a pattern of stronger responses (positive or negative) of species than ecosystems, more positive responses at lower trophic levels and strong indirect interactions in food-webs. Common emergent themes were as follows: OA drives planktonic systems toward the microbial loop, reducing energy transfer to zooplankton and fish; and nutrient/food availability ameliorates negative impacts of OA. We identify several key areas for further research, notably the need for OA-relevant biogeochemical and ecosystem models, and understanding the ecological and evolutionary capacity of Baltic-Skagerrak ecosystems to respond to $\mathrm{OA}$ and other anthropogenic drivers.
\end{abstract}

Keywords Baltic - Ecosystem services - Eutrophication · Indirect effects · Ocean acidification · Warming

\section{INTRODUCTION}

Globally, increasing emissions of anthropogenic carbon dioxide $\left(\mathrm{CO}_{2}\right)$ are causing warming of the oceans, melting of sea ice, glaciers and ice sheets, and ocean acidification. ${ }^{1}$ For the Baltic-Skagerrak System (Fig. 1), these processes are reflected in rising sea level, increased precipitation (leading to locally reduced salinity), increased flooding, coastal erosion, and flow of organic and inorganic matter into coastal waters. All of these add to the direct and indirect effects of ocean acidification in different ways.
Anthropogenic ocean acidification arises when anthropogenic emissions of $\mathrm{CO}_{2}$ elevate atmospheric $\mathrm{CO}_{2}$ concentration, resulting in elevated partial pressure of $\mathrm{CO}_{2}$ $\left(\mathrm{pCO}_{2}\right)$ in the oceans and a corresponding decrease in ocean $\mathrm{pH}$. But $\mathrm{pH}$ also varies naturally in the oceans over diurnal and seasonal timescales. This arises due to biogeochemical drivers, such as temperature, salinity, and input of terrestrial organic matter and subsequent decay, as well as through biological processes such as primary production (which increases $\mathrm{pH}$ ) and respiration (which decreases $\mathrm{pH}$ ). While the effects of these drivers on marine life are relatively well understood individually, we know less about the effects of combinations of drivers on single species, and little about their effects on entire coastal ecosystems, communities, and society in general-especially for ocean acidification.

Ocean acidification (hereafter, 'OA') is recognised in the United Nations' Sustainable Development Goal 14.3 "Minimize and address the impacts of ocean acidification...", and has been identified as a cause of substantial impacts on marine ecosystems (Gattuso et al. 2015; Riebesell and Gattuso 2015). Although OA is a global issue caused by rising atmospheric $\mathrm{CO}_{2}$ concentrations (Doney et al. 2009), the degree and effects of OA are geographically heterogeneous due to regional differences in air:sea fluxes and ocean chemistry (Steffen et al. 2015). Multiple recent reviews of OA have concluded that effects on species are generally negative, but that responses vary markedly among species (e.g. Kroeker et al. 2013),

\footnotetext{
${ }^{1}$ Since the onset of industrialisation, global atmospheric $\mathrm{CO}_{2}$ levels have increased by $\sim 45 \%$ (from 270 to today's $400 \mu \mathrm{atm}$ ), causing seawater $\mathrm{pH}$ to decrease by about 0.1 units. $\mathrm{pH}$ is projected to decrease by another 0.3 units by 2100 . Because of the logarithmic nature of the $\mathrm{pH}$ scale, these changes equate to increases of $\sim 30 \%$ and $\sim 100 \%$ (respectively) in the hydrogen ion content of seawater (Box 1).
} 


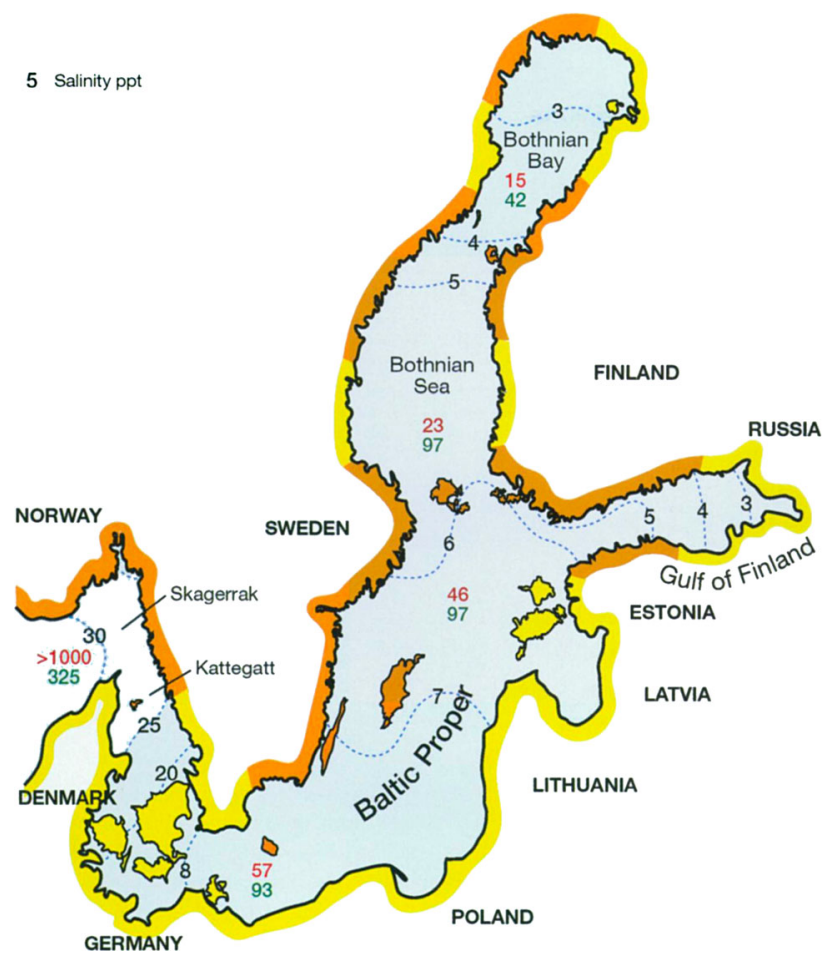

Fig. 1 Map of the Baltic-Skagerrak System (Skagerrak, Kattegatt, Baltic Proper, Bothnian Sea, Bothnian Bay, Gulf of Finland). We use the term "Baltic-Skagerrak System" to refer to the entire region from the Skagerrak to the Bothnian Bay. Modified from Rönnbäck et al. (2007)

notably between field and the laboratory (e.g. Wahl et al. 2018), and that OA effects can be strongly modified by interactions with other drivers (Gunderson et al. 2016) and species (Kroeker et al. 2017). Much of this recent work highlights the importance of non-linear processes, especially when multiple environmental drivers interact (e.g. Albright et al. 2016a; Mostofa et al. 2016; Kroeker et al. 2017). For example, Gao et al. (2018) found that the interactive effects of $\mathrm{OA}$ and ocean warming on phytoplankton physiology could be synergistic, neutral, or antagonistic depending on species and prevailing environmental conditions. Equivalent responses have been reported at higher trophic levels (Harvey et al. 2013). At a broader scale, OA impacts on marine ecosystems have the potential to affect a wide range of ecosystem services (ESs). Although a general picture of OA effects on ESs is yet to emerge (Falkenberg and Tubb 2017), some specific OArelated dis-benefits have already been identified (e.g. oysters, Lemasson et al. 2017). Addressing these OA impacts directly may be difficult, however, manipulating non-OA drivers affecting ecosystem resilience or adaptation has been suggested as a viable management policy option to mitigate OA effects (Albright et al. 2016b).

The geological record provides an important environmental archive of past OA events and how past marine ecosystems have responded to changes in $\mathrm{pH}$ and ocean biogeochemistry (e.g. Harnik et al. 2012; Hönisch et al.
2012). The most recent global event occurred during the last deglaciation, when atmospheric $\mathrm{CO}_{2}$ increased $30 \%$ (from 189 to $265 \mu \mathrm{atm}$ ), leading to a $\sim 0.15$ unit drop in sea surface $\mathrm{pH}$ in the open ocean (e.g. Hönisch and Hemming, 2005). This change corresponded to a decrease of 0.002 units per 100 years, which is much slower than current rates (Zeebe et al. 2016). The coastal seas of the Baltic-Skagerrak System were subjected to considerable environmental changes during the deglaciation and disentangling the potential effect of a regional change in $\mathrm{pH}$ (and its magnitude) remains to be done.

The Baltic-Skagerrak System comprises one of the world's largest permanent salinity gradients (Fig. 1) from the high salinity Skagerrak shores (salinity $\sim 30)^{2}$ to the shallow, almost freshwater archipelagos of the northern Bothnian Bay (salinity 3). This gradient not only contains multiple different ecosystems, but also creates differences in seawater chemistry that alter the process, and effects, of OA. Hence ocean acidification will impact various parts of the system very differently.

In addition to drivers ${ }^{3}$ such as $\mathrm{OA}$ and warming that are changing marine systems on a global scale, the BalticSkagerrak System is also subject to local pressures from eutrophication, freshening, and pollution, resulting from agriculture, tourism, fishing, aquaculture, etc. Local differences in the strength and timing of these drivers, and the natural heterogeneity of coastal seas, create far greater variability and change than that seen in the open ocean. Coastal marine ecosystems of the Baltic have changed markedly during the past 40 years, which is partly attributable to local and regional warming and freshening (Olsson et al. 2012), as well as eutrophication (Olsson et al. 2015). The role of OA in this context is poorly known, not least because most biologists were unaware of its importance until relatively recently (Gattuso and Hansson 2011).

Here we (i) outline the current state of knowledge related to $\mathrm{OA}$ in the Baltic-Skagerrak System, as an example of OA-related processes in a brackish coastal sea; (ii) identify knowledge gaps; and (iii) suggest priorities for future research. We focus on the mechanisms that underlie $\mathrm{OA}$, its interactions with other coastal drivers, and its impacts on biogeochemical processes, marine species, and ecosystems. Unless stated otherwise, we consider the biological consequences of "near-future" OA (i.e. $\mathrm{pCO}_{2}$ levels up to $\sim 1300 \mu \mathrm{atm}$, van Vuuren et al. 2011). Information summarised here was obtained from ISI Web

\footnotetext{
2 The practical salinity scale is dimensionless and therefore we refer to salinity throughout this document simply as a number.

${ }^{3}$ Connell et al. 2018 note the duality of $\mathrm{CO}_{2}$ as both a resources and a stressor. Therefore, as far as practicable, we follow the DPSIR definition of "drivers" ("...complex phenomena governing the direction of ecosystem change, which could be of human and natural origin"), of Oesterwind et al. (2016).
} 
of Science and EconLit databases using the search terms "ocean acidification" or " $\mathrm{pCO}_{2}$ ", together with "Baltic, Kattegat, Skagerrak or Finland". Additional examples, including non-OA examples, were searched for on an ad hoc basis. A companion manuscript (Jagers et al. 2018) addresses the socio-economic background to, and prospective societal solutions for, OA in Swedish coastal seas. Throughout, we use the term "Baltic-Skagerrak System" to refer to all waters from the Skagerrak to the Bothnian Bay, and the relevant regional terms for the different components of the Baltic system (Fig. 1).

\section{BIOGEOCHEMICAL BASIS OF OCEAN ACIDIFICATION IN THE BALTIC-SKAGERRAK SYSTEM}

The surface ocean continuously exchanges $\mathrm{CO}_{2}$ with the atmosphere. When atmospheric partial pressure of $\mathrm{CO}_{2}$ $\left(\mathrm{pCO}_{2}\right)$ is greater than that in the oceans, there is a flux of $\mathrm{CO}_{2}$ from the atmosphere into the oceans (and vice versa). This flux is influenced by primary production-which reduces seawater $\mathrm{pCO}_{2}$ in the summer, and by decomposition and biomineralisation-which cause the release of $\mathrm{CO}_{2}$ in the winter. These processes create a seasonal cycle of $\mathrm{pCO}_{2}$ both in the atmosphere and the ocean. However, as the atmosphere mixes much faster than the ocean, the atmospheric signal is diluted and far less pronounced: for instance the seasonal amplitude in atmospheric $\mathrm{pCO}_{2}$ at the

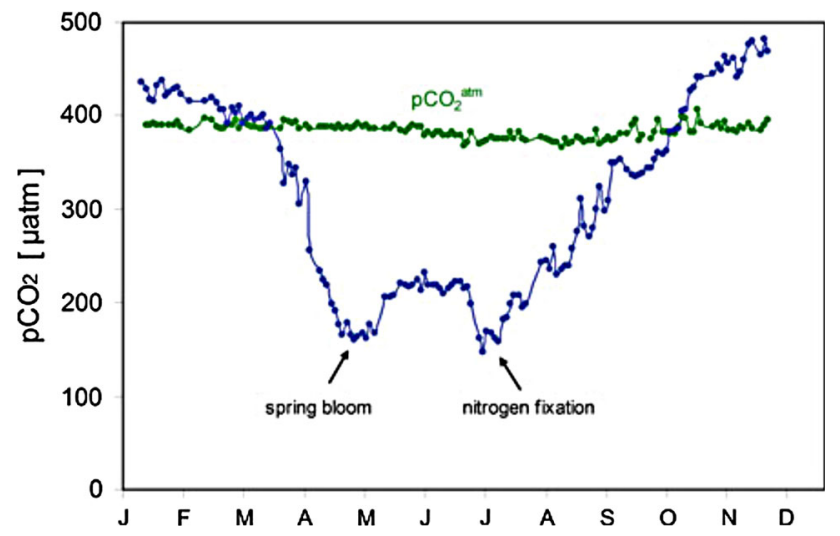

Fig. 2 Seasonal changes in phytoplankton productivity absorb dissolved $\mathrm{CO}_{2}$ in the water (blue line) during spring and summer, creating "draw-down" relative to the level of $\mathrm{CO}_{2}$ in the overlying atmosphere (green line). Data from central Baltic Sea, taken from Schneider et al. (2015) latitude of Sweden is $\sim 10 \mu \mathrm{atm}$, while that in the coastal ocean can be several hundred $\mu$ atm (Fig. 2).

Since the onset of the industrial revolution, seasonally averaged global atmospheric $\mathrm{pCO}_{2}$ has risen from around $280 \mu \mathrm{atm}$ to $>400 \mu \mathrm{atm}$ today, and consequently the average $\mathrm{pCO}_{2}$ of the surface ocean has also increased (Bates et al. 2012). Seasonal fluctuations in $\mathrm{pCO}_{2}$ are superimposed on this mean increase, leading to greater extremes of $\mathrm{pCO}_{2}$. Increasing atmospheric $\mathrm{pCO}_{2}$ reduces ocean $\mathrm{pH}$, but the extent of $\mathrm{pH}$ reduction depends not only on the $\mathrm{pCO}_{2}$ itself, but also on other properties of the seawater, notably the existing $\mathrm{pH}$, the buffering capacity (the "alkalinity") of the seawater, and to a small extent the temperature (see Box 1). The chemical buffer capacity, i.e. the change in $\mathrm{pH}$ for a given change in $\mathrm{pCO}_{2}$, is determined by the total concentration of all the bases in the seawater, measured as total alkalinity. In most of the world's coastal oceans, alkalinity is broadly correlated with salinity, and therefore buffer capacity typically decreases with decreasing salinity. However, in the different basins of the Baltic-Skagerrak System, this alkalinity:salinity relationship is complicated by large differences in local geology that influence alkalinity independently (Omstedt et al. 2009; see Box 2). This results in the different low-salinity basins of the Baltic-Skagerrak System having different pHs despite having similar salinities; i.e. low $\mathrm{pH}$ in the northern Bothnian Bay and inner Gulf of Finland due to input of low alkalinity river runoff, and high $\mathrm{pH}$ in the Gulf of Riga resulting from inflow of high alkalinity runoff (Fig. 3).

\begin{tabular}{|l|}
\hline Box 1: Atmospheric $\mathrm{CO}_{2}$ and the acidification of seawater \\
\hline Unlike the other atmospheric gases, when $\mathrm{CO}_{2}$ dissolves in \\
seawater it reacts chemically with the water: \\
$\mathrm{CO}_{2}(\mathrm{aq})+\mathrm{H}_{2} \mathrm{O} \leftrightarrows \mathrm{H}_{2} \mathrm{CO}_{3} \leftrightarrows \mathrm{H}^{+}+\mathrm{HCO}_{3}^{-} \leftrightarrows 2 \mathrm{H}^{+}+\mathrm{CO}_{3}^{2-}$ \\
The pH of the seawater determines which of these chemical species \\
dominate. Higher pH drives the system farther to the right. At \\
seawater pH's typical of Swedish coastal waters (7.5-8.5) the \\
carbonate system is dominated by the $\mathrm{HCO}_{3}^{-}$terms, and hence \\
dissolving $\mathrm{CO}_{2}$ in seawater leads to an increase in proton $\left(\mathrm{H}^{+}\right.$) \\
concentration, and hence increased acidity. Dissolved inorganic \\
carbon (DIC) buffers the dissolution of $\mathrm{CO}_{2}$ in seawater by the \\
$\mathrm{CO}_{3}{ }^{2-}$ ion reacting with the $\mathrm{CO}_{2}$. Because DIC and alkalinity \\
decline from the Swedish west-coast, through the Baltic Proper and \\
into the Bothnian Bay, the effects of increasing pCO \\
the Bare greater in \\
Baltic than on the west coast (see main text).
\end{tabular}




\section{Box 2: Salinity, alkalinity and $\mathrm{pH}$ in the Baltic}

In the Baltic, sea surface salinity is determined by the combination of runoff of freshwater together with limited exchange of seawater with the North Sea. In those parts of the Baltic system most distant from the North Sea (Bothnian Bay and eastern Gulf of Finland), the salinity is below 3, rises to around 7 in the Baltic Proper, and then rises rapidly from $\sim 8$ in the southern Danish straits to $\sim 15$ in the Kattegat just a hundred $\mathrm{km}$ or so to the north. Salinity continues to rise to the north and west, reaching 30 in the western Skagerrak (Fig. 1). The alkalinity of river runoff varies depending on the geology of the drainage basin. The northern Bothnian Bay, which is largely surrounded by granite bedrock, has relatively low alkalinity and $\mathrm{pH}$ because the alkalinity of the runoff is low. In contrast, the limestone bedrock that characterises the watersheds flowing into the Gulf of Riga has very high alkalinity, and thus $\mathrm{pH}$ in the Gulf of Riga is much higher (Fig. 3). Recent work shows increased weathering of bedrock, increases alkalinity and offsets the effects of ocean acidification (Müller et al. 2016).

Differences in alkalinity combine with differences in the extent of primary production to cause greater seasonal variability in $\mathrm{pH}$ in parts of the Baltic compared to the Kattegatt/Skagerrak (Fig. 4). This effect is amplified by the nutrient-rich conditions in the Baltic that cause a stronger "draw-down" of $\mathrm{CO}_{2}$ during the productive season, which results in higher $\mathrm{pH}$ during the summer (Fig. $4 \mathrm{~b}$ ). These data are for the open Baltic and Kattegat: in shallow coastal embayments, the processes contributing to this variation generate even stronger $\mathrm{pH}$ variation (e.g. Saderne et al. 2013; Wallace et al. 2014; Carstensen et al. 2018).

Seasonal changes in $\mathrm{CO}_{2}$ uptake and release also have implications for other important chemical processes in coastal seas. Photosynthesis by micro- and macroalgae, and marine plants, consumes "acidic" $\mathrm{CO}_{2}$ and hydrogen ions $\left(\mathrm{H}^{+}\right)$(see Box 3). This causes $\mathrm{pH}$ to increase in summer while the decomposition of organic matter, produces hydrogen ions and lowers $\mathrm{pH}$, reversing this process in winter (Fig. 2). Primary production occurs close to the surface in the surface-lit (photic) zone, but much of the decomposition occurs after this production has died and settled to the seafloor, i.e. deep in the water column or at the sediment surface. In waters with limited exchange, this can completely deplete the available oxygen near the seabed, resulting in bottom waters with very low oxygen ("hypoxic", i.e. $<30 \% \quad \mathrm{O}_{2}$ saturation), or no oxygen ("anoxic"). This influences seawater chemistry resulting in increased solubility of some metals (notably manganese and iron), and in some cases the production of elemental sulphur, all of which influence seawater $\mathrm{pH}$ (see Box 3).

In the Baltic-Skagerrak System, nutrient emissions from waste-water treatment and agricultural runoff have caused eutrophication, such that areas of hypoxia/anoxia have increased (Conley et al. 2009, 2011). Anoxia amplifies the effects of eutrophication through chemical reactions between iron (III) and phosphate, which in oxic sediments

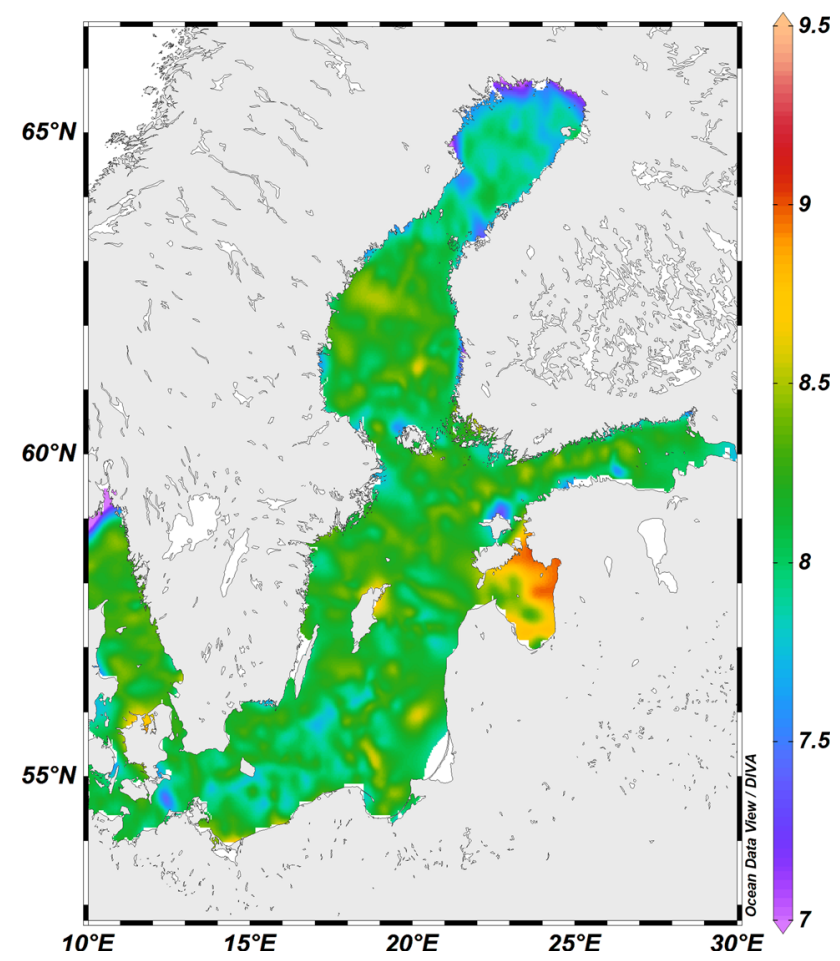

Fig. 3 Long-term mean surface water $(0-20 \mathrm{~m}) \mathrm{pH}$ in the BalticSkagerrak System, (C) Adam Ulfsbo. Data are interpolation of historical records collected during all seasons between 1911 and 2003, and therefore only show general patterns in $\mathrm{pH}$ distribution. For more information, including station positions, see Hjalmarsson et al. (2008)

form precipitations that trap phosphate, but which is dissolved and released when the sediment becomes anoxic and iron(III) is reduced to iron(II). Thus, in anoxic waters phosphate is released back to the water column where, in time, it is mixed up to the surface where it stimulates primary productivity, leading to higher summer $\mathrm{pH}$, as illustrated in the Baltic Proper (Fig. 4).

In addition to influencing alkalinity, river runoff also contains dissolved and particulate organic matter, some of which decays by microbial activity, adding to local deoxygenation and ocean acidification. The dissolved fraction has further impact on $\mathrm{pH}$ as these dissolved molecules contain carboxyl groups (organic acids) and thus can reduce $\mathrm{pH}$ further. Although uncertainty is large, climate model projections for the coming century show increased precipitation over northern Scandinavia, particularly in the winter months (Christiansen et al. 2015), which implies increased flux of terrestrial organic matter to the coastal seas, potentially adding to OA and deoxygenation.

Despite many years of monitoring data, seasonal variation and methodological issues preclude reliable detection of long-term trends in measurements of seawater $\mathrm{pH}$ in Baltic-Skagerrak System. Recent modelling, however, 

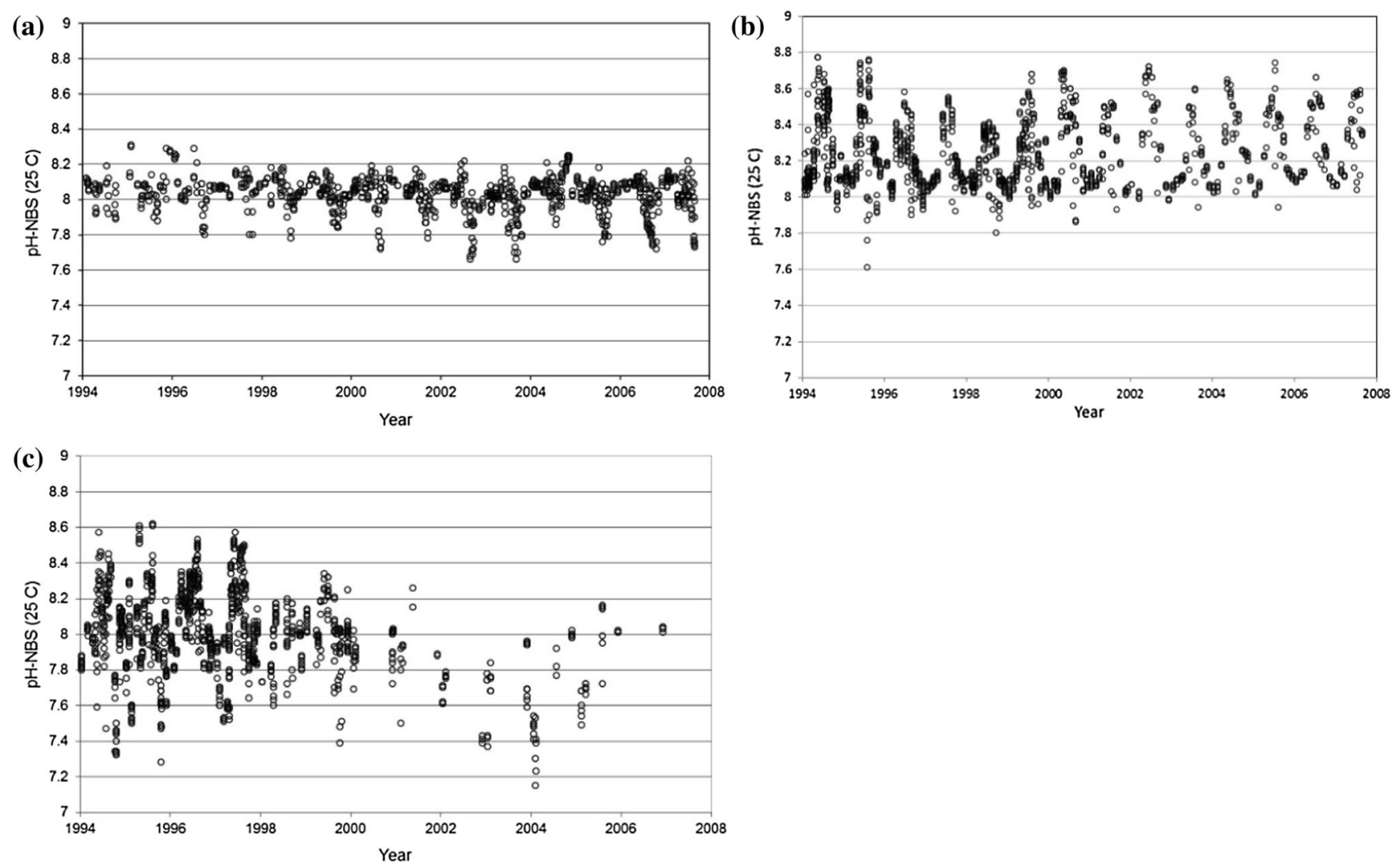

Fig. 4 Time series of $\mathrm{pH}$ in the top $20 \mathrm{~m}$ of the water column showing seasonal fluctuations in the open Kattegat (a), Baltic Proper (b) and Bothnian Bay (c). Note that the observational frequency decreased substantially after 2000 in the Bothnian Sea (Data on pH $\mathrm{NBS}_{\mathrm{NB}} \mathrm{scale}$, measured at $25{ }^{\circ} \mathrm{C}$ from SMHI: http://sharkdata.se/about/)

projects that the combination of this variation with increasing anthropogenic atmospheric $\mathrm{CO}_{2}$ will lead to greater $\mathrm{pH}$ variation and lower $\mathrm{pH}$ minima in the surface waters (Fig. 6). Importantly, although projected average $\mathrm{pH}$ in the scenario plotted in Fig. 6 reaches 7.8 in the last decade of this century, winter minimum $\mathrm{pH}$ already begins to fall below this value in the year 2040. Thus, for species that are sensitive to low $\mathrm{pH}$, the seasonal effects of acidification may be felt far sooner than would be expected from the projected mean annual $\mathrm{pH}$.

\section{DIRECT EFFECTS OF OCEAN ACIDIFICATION}

Ocean acidification impacts the species of the Baltic-Skagerrak System directly, interactively (i.e. in combination with other drivers), and indirectly through competitive and trophic interactions in the ecosystem. In this section, we consider the direct effects of OA on species. The interactive and indirect effects of OA are considered in subsequent sections.
Responses of plankton in the Baltic-Skagerrak System to $\mathrm{OA}$ in the form of elevated $\mathrm{pCO}_{2}$ are highly variable, and often context dependent. This applies both among species/OTUs (operational taxonomic units), but also at the community level (Table 1). At the species/OTU level, bacterioplankton abundance typically shows no (or small) responses to OA (e.g. Baltic Proper, Lindh et al. 2013), but at the community level indirect responses can manifest as shifts in community composition, which can be linked to shifts in the phytoplankton community (western Baltic, Bergen et al. 2016; Gulf of Finland, Hornick et al. 2017). Responses of phytoplankton tend to be more variable. Cyanobacterial species in different functional groups display positive, negative, or no, responses to elevated $\mathrm{pCO}_{2}$ (western Baltic, Czerny et al. 2009; Eichner et al. 2014), and responses of spring-bloom diatoms and dinoflagellates also differ. For example, in the Skagerrak, growth rates of diatoms increased under OA (Kremp et al. 2012), but not growth of a toxic dinoflagellate (although toxin production increased, Kremp et al. 2012). Calcification and growth of coccolithophorids under OA varies among clones (multiple locations, Langer et al. 2009) and species (Meyer and 
Box 3: Chemical consequences of ocean acidification in the Baltic-Skagerrak System

In the surface mixed layer of the oceans, the photosynthetic capture of light energy to combine $\mathrm{CO}_{2}$, macro-nutrients (such as nitrate and phosphate), and micro-nutrients in the form of trace metals $\left(\mathrm{Me}^{2+}\right.$, such as iron(II)) to create organic matter and oxygen can be formulated as $140 \mathrm{CO}_{2}+16 \mathrm{H}^{+}+16 \mathrm{NO}_{3}^{-}+\mathrm{HPO}_{4}^{2-}+\mathrm{Me}^{2+}+123 \mathrm{H}_{2} \mathrm{O} \rightarrow\left(\mathrm{CH}_{2} \mathrm{O}\right)_{91}\left(\mathrm{CH}_{2}\right)_{16}\left(\mathrm{NHCH}_{2} \mathrm{CO}\right)_{16}\left(\mathrm{CHPO}_{4} \mathrm{Me}\right)+172 \mathrm{O}_{2}$

Decomposition of sedimenting organic matter in deeper water runs in the opposite direction, releasing $\mathrm{CO}_{2}$ and $\mathrm{H}^{+}$. In the following

formulation, this $\mathrm{CO}_{2}$ release is illustrated by balancing it to the bicarbonate ion, $\mathrm{HCO}_{3}{ }^{-}$, the dominating form of dissolved inorganic carbon at typical seawater $\mathrm{pH}($ Box 1$)$.

$\left(\mathrm{CH}_{2} \mathrm{O}\right)_{91}\left(\mathrm{CH}_{2}\right)_{16}\left(\mathrm{NHCH}_{2} \mathrm{CO}\right)_{16}\left(\mathrm{CHPO}_{4} \mathrm{Me}\right)+172 \mathrm{O}_{2}+17 \mathrm{H}_{2} \mathrm{O} \rightarrow 140 \mathrm{HCO}_{3}^{-}+156 \mathrm{H}^{+}+16 \mathrm{NO}_{3}^{-}+\mathrm{HPO}_{4}^{2-}+\mathrm{Me}^{2+}$

Thus decomposition produces hydrogen ions, and hence lowers $\mathrm{pH}$. This reaction normally occurs deep in the water column or at the sediment surface. In waters with limited exchange, the decomposition process (reaction 2) can sometimes completely deplete the available oxygen, resulting in strongly hypoxic or anoxic bottom water. Under these circumstances, other "electron acceptors" are needed to replace oxygen in the decomposition process. The most energetically favourable electron acceptor after oxygen is nitrate, and hence in hypoxic and anoxic areas, decomposition leads to denitrification:

$\left(\mathrm{CH}_{2} \mathrm{O}\right)_{91}\left(\mathrm{CH}_{2}\right)_{16}\left(\mathrm{NHCH}_{2} \mathrm{CO}\right)_{16} \mathrm{C}\left(\mathrm{MeHPO}_{4}\right)+112 \mathrm{NO}_{3}^{-} \rightarrow 140 \mathrm{HCO}_{3}^{-}+12 \mathrm{H}^{+}+56 \mathrm{~N}_{2}+16 \mathrm{NH}_{4}^{+}+\mathrm{HPO}_{4}^{2-}+\mathrm{Me}^{2+}+23 \mathrm{H}_{2} \mathrm{O}$

When comparing reactions (2) and (3), it can be seen that denitrification generates far fewer hydrogen ions per bicarbonate ion produced. If decomposition proceeds to deplete all the nitrate, then other electron acceptors step in. In seawater, these are (in order) manganese(IV), iron(III) and sulphate. When these are used as electron acceptors the following reactions (4-6) occur (here organic matter is simplified to "carbohydrates"; $\mathrm{CH}_{2} \mathrm{O}_{(\text {org })}$ ):

$\mathrm{CH}_{2} \mathrm{O}_{(\mathrm{org})}+2 \mathrm{Mn}(\mathrm{IV}) \mathrm{O}_{2}+3 \mathrm{H}^{+} \rightarrow \mathrm{HCO}_{3}^{-}+2 \mathrm{H}_{2} \mathrm{O}+2 \mathrm{Mn}(\mathrm{II})^{2+}$

$\mathrm{CH}_{2} \mathrm{O}_{(\text {org })}+4 \mathrm{Fe}(\mathrm{III}) \mathrm{OOH}+7 \mathrm{H}^{+} \rightarrow \mathrm{HCO}_{3}^{-}+6 \mathrm{H}_{2} \mathrm{O}+4 \mathrm{Fe}(\mathrm{II})^{2+}$

$\mathrm{CH}_{2} \mathrm{O}_{(\text {org })}+0.5 \mathrm{SO}_{4}^{2-} \rightarrow \mathrm{HCO}_{3}^{-}+0.5 \mathrm{H}^{+}+0.5 \mathrm{HS}^{-}$

These reactions have very different impacts on $\mathrm{pH}$ as both manganese and iron reduction consume $\mathrm{H}^{+}$, whereas sulphate reduction produces $\mathrm{H}^{+}$. An important consequence of this is that the sulphide bottom-water that occurs in the Baltic Proper has close to constant $\mathrm{pH}$, even if the sulphide concentration increases with depth (Fig. 5). Note that temperature affects these biogeochemical reactions as well as the solubility of gases, which results in lower $\mathrm{pH}\left(\right.$ more $\left.\mathrm{CO}_{2}\right)$ in colder waters in equilibrium with the atmosphere.

These biochemical processes also occur in the sediment, especially in surface layers where "bioturbation" by the fauna causes mixing of interstitial water with deep waters in the water column. When anoxic water meets oxic water the reduced chemical species are oxidised in reactions that also involve hydrogen ions. For example, when iron(II) is oxidised $\mathrm{H}^{+}$is produced:

$\mathrm{Fe}(\mathrm{II})^{2+}+2 \mathrm{H}_{2} \mathrm{O} \rightarrow \mathrm{Fe}(\mathrm{III}) \mathrm{OOH}+2 \mathrm{H}^{+}$

But when hydrogen sulphide is oxidised to elemental sulphur $\mathrm{H}^{+}$is consumed:

$\mathrm{HS}^{-}+0.5 \mathrm{O}_{2}+\mathrm{H}^{+} \rightarrow \mathrm{H}_{2} \mathrm{O}+\mathrm{S}^{0}$

Or if iron sulphide precipitates $\mathrm{H}^{+}$is produced:

$\mathrm{Fe}(\mathrm{II})^{2+}+\mathrm{HS}^{-} \rightarrow \mathrm{FeS}(\mathrm{s})+\mathrm{H}^{+}$
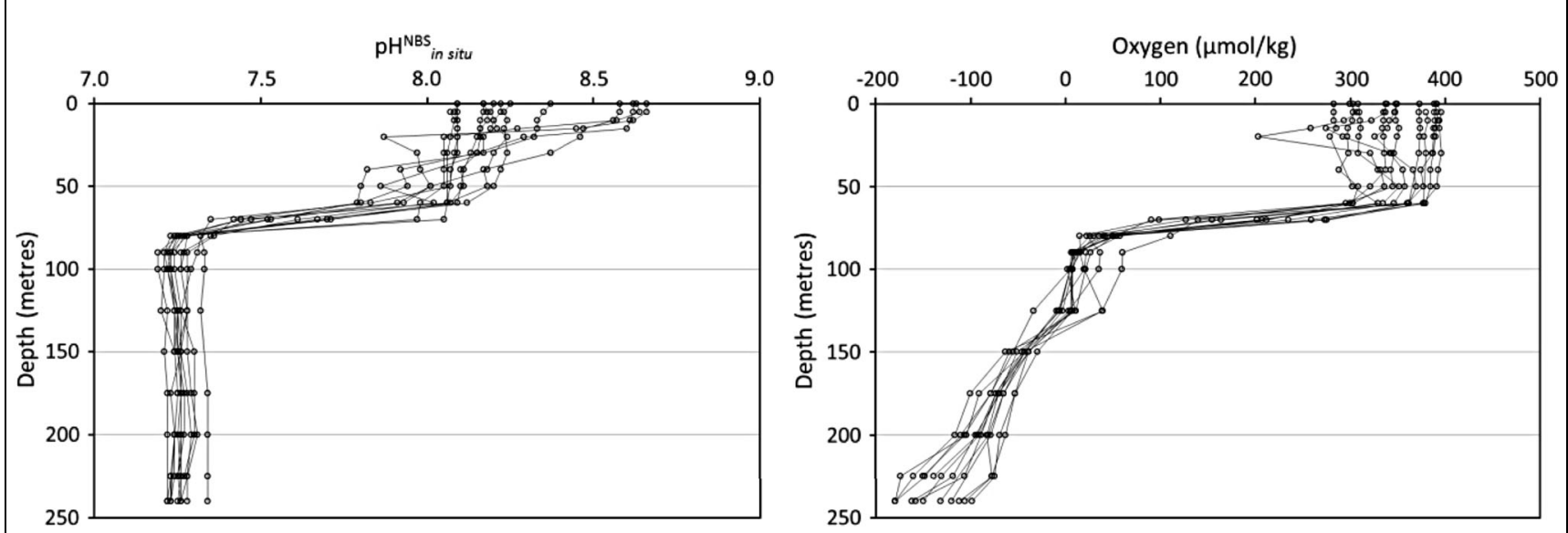

Fig. 5 Profiles of $\mathrm{pH}$ and oxygen in the Gotland Basin for all months during 2008 (after Ulfsbo et al. 2011). Note that negative oxygen concentrations represent sulphide

Riebesell, 2015), illustrating the difficulties that intra- and interspecific variation create for making generalisations (Eichner et al. 2014; note that coccolithophorids are largely restricted to the higher salinity Kattegat and Skagerrak). At the community level, mesocosm studies show OA can influence phytoplankton community structure, with subtle 


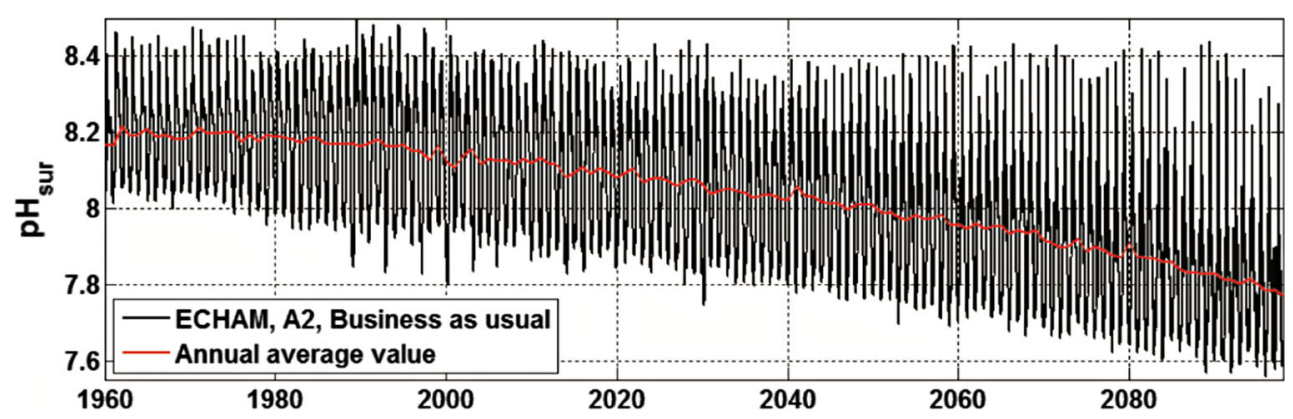

Fig. 6 Daily $\mathrm{pH}$ values for surface water in the Eastern Gotland Basin projected from the ECHAM global climate model and the SRES A2 "business as usual" scenario. Note that due to increased nutrient load that stimulates photosynthetic uptake of $\mathrm{CO}_{2}$ from surface waters, summer maximum $\mathrm{pH}$ remains mostly constant until $\sim 2090$, whereas winter minimum $\mathrm{pH}$ declines almost linearly throughout the modelled period. (From Omstedt et al. 2012)

shifts in dominant taxa such as diatoms, cryptophytes, and cyanobacteria, but stronger shifts in sub-dominant taxa (western Baltic, Sommer et al. 2015; Gulf of Finland, Paul et al. 2016a, b). Overall phytoplankton productivity seems to increase under OA, although there is also a strong seasonal component to this response (Skagerrak, Eberlein et al. 2017).

Among benthic macrophytes, macroalgae show negative, no, or positive, responses to increasing $\mathrm{pCO}_{2}$ (reviewed by Takolander et al. 2017). Elevated $\mathrm{pCO}_{2}$ stimulated growth of filamentous "opportunistic" greenand red-algae (eastern Baltic, Pajusalu et al. 2013), and of the brown alga Fucus, from the western Baltic and Baltic Proper (Al-Janabi et al. 2016a), and had small positive effects on fertilisation success in Fucus (western Baltic, Graiff et al. 2017). Other experiments with Fucus found no (or minor) effects of OA (Pajusalu et al. 2013; western Baltic, Werner et al. 2016; Raddatz et al. 2017). In contrast, seagrasses generally respond more uniformly, and positively, to elevated $\mathrm{pCO}_{2}$, although reported effects are relatively small (Skagerrak, Eklöf et al. 2012; Alsterberg et al. 2013; Portugal, Repolho et al. 2017). In cases where $\mathrm{OA}$ has been investigated in combination with warming, responses to $\mathrm{OA}$ are frequently overshadowed by the interactive effects of warming (see below).

Studies of zooplankton in the Baltic-Skagerrak System have focused on copepods, which show a high degree of phenotypic buffering to OA in a variety of traits such as body size, reproduction, and behaviour (e.g. Vehmaa et al. 2012, 2016; Almén et al. 2016, 2017; Lischka et al. 2017). Some of these responses have been shown to be enhanced by trans-generational inheritance of plasticity, whereby parental exposure to OA generates more OA-tolerant offspring (Kattegatt, Thor and Dupont, 2015; Baltic Proper, Vehmaa et al. 2016). This plasticity has limits, however, and high $\mathrm{pCO}_{2}$ still had negative effects (Acartia, 1230 $\mu$ atm $\mathrm{CO}_{2}$, Vehmaa et al. 2016). Importantly, susceptibility of copepods to OA has been shown to vary with location and environmental history (Spitzbergen vs. Skagerrak, Thor and Oliva, 2015). This work also showed that different energetic functions (e.g. ingestion and respiration) can respond differently to OA, yielding non-linear responses at the whole-organism level (Thor and Oliva, 2015). Data for OA responses of gelatinous plankton in the Baltic-Skagerrak System are lacking, however, studies of relevant species from nearby regions indicate they are generally tolerant of OA (Aurelia, North Sea, AlgueróMuñiz et al. 2016), or respond positively (Oikopleura, North Sea, Winder et al. 2017; Bouquet et al. 2018). In summary, these data suggest that the impacts of OA on zooplankton species in the Baltic-Skagerrak System are likely to be small. Interactions among species and effects on the plankton community as a whole are considered in the following section.

In contrast to zooplankton, benthic animals in the BalticSkagerrak System generally respond either negatively or neutrally to OA (to date there is one report of a positive response; seastar, Skagerrak, Dupont et al. 2010). Negative responses include reduced embryonic and larval survival (brittle stars, Skagerrak, Dupont et al. 2008; bivalves, Baltic, Jansson et al. 2016; Skagerrak, Ventura et al. 2016; van Colen et al. 2018), delayed larval development (sea urchins, Skagerrak, Stumpp et al. 2011a), and immune suppression (crustaceans, Skagerrak, Wood et al. 2014; Hernroth et al. 2015; see Table 1 for full list). Reports of no, or minor, responses to OA include effects on fertilisation success (bivalves, Skagerrak, Havenhand and Schlegel 2009), adult growth (bivalves, Baltic, Thomsen and Melzner 2010), larval development (crustaceans, Skagerrak, Baltic, Pansch et al. 2012, 2013), and metabolic scaling (echinoderms, Skagerrak, Carey et al. 2014; see 


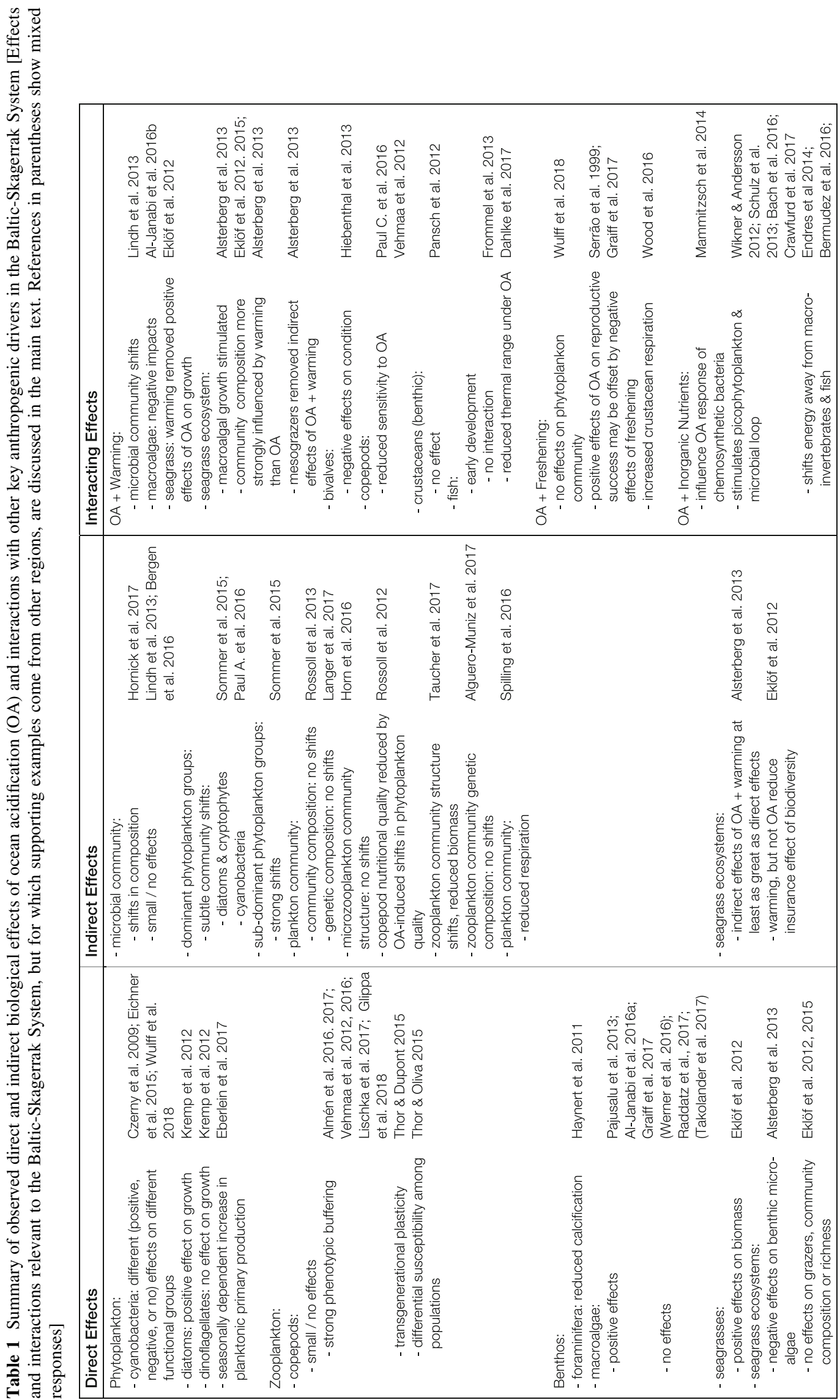




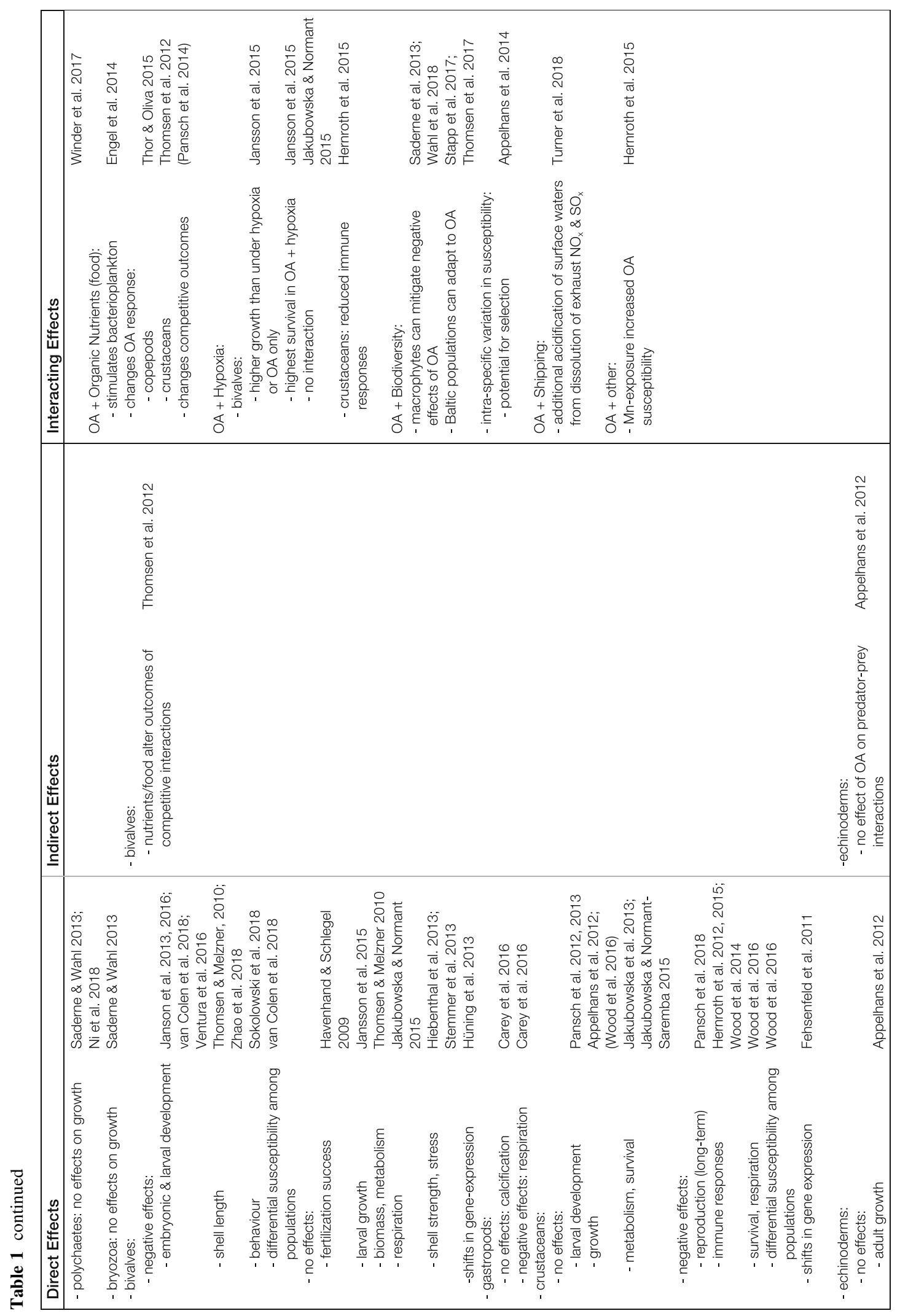

(C) The Author(s) 2018 


$$
=
$$


Table 1 for full list). Notably, bivalves from parts of the western Baltic that routinely experience strong upwelling/ low $\mathrm{pH}$ events appear to be tolerant of extreme levels of OA (Thomsen and Melzner 2010; Thomsen et al. 2013), indicating that here too environmental history may be an important determinant of tolerance (Thomsen et al. 2017). As noted earlier for copepods, trans-generational acclimation to $\mathrm{OA}$ has also been reported for benthic invertebrates (e.g. Dupont et al. 2013; Hu et al. 2018), and here too, prior environmental history appears to influence tolerance (Hu et al. 2018). Dissecting the effects of transgenerational plasticity from other forms of plasticity is complex and more, targeted experimentation is required before generalisations can be made on the potential for trans-generational plasticity in benthic animals (Torda et al. 2017).

Two bivalve species in particular, Mytilus trossulus/ edulis and Macoma baltica, are key components of BalticSkagerrak ecosystems, and fundamental to benthic ecosystem functioning in the region (Niiranen et al. 2013). In both cases, these species show few or no responses to OA: Mytilus from the Baltic-Skagerrak System tend to be highly insensitive to OA (Thomsen and Melzner 2010; Thomsen et al. 2010, 2013; Jakubowska and Normant 2015; Ventura et al. 2016), and this response appears to be heritable (Stapp et al. 2017; Thomsen et al. 2017). Although larvae of Macoma baltica from the eastern Baltic are negatively impacted by OA (Jansson et al. 2013, 2016; unlike the adjacent North Sea, van Colen et al. 2018), juvenile survival was positively impacted by OA (in combination with hypoxia, Jansson et al. 2015), and adult Macoma appear to be unaffected, even by very low $\mathrm{pH}$ (southern Baltic, Jakubowska and Normant-Saremba 2015). Thus, it seems unlikely that OA will have substantive impacts on these key bivalves - and hence on the primary benthic component of benthic-pelagic couplingin the Baltic-Skagerrak system.

Commercially and ecologically important fish species in the Baltic-Skagerrak System show generally, but not exclusively, negative direct responses to OA. Growth of larval halibut, herring, and cod were all negatively impacted by OA (Baltic, Franke and Clemmesen 2011; Frommel et al. 2013; Skagerrak, Gräns et al. 2014; Stiasny et al. 2016), but OA had no effects on sperm motility or swimming performance of adult cod (Baltic, Melzner et al. 2009; Frommel et al. 2010). Incorporating the effects of $\mathrm{OA}$ in stock recruitment models led to a projected reduction in recruitment of western Baltic cod stocks by $90 \%$ (Stiasny et al. 2016). Work on non-commercial species has shown the potential for trans-generational effects that can increase offspring tolerance to OA (sticklebacks, North Sea, Schade et al. 2014), which may ameliorate these effects. The extent to which such effects operate in commercially important species in the BalticSkagerrak System is not yet known, however, and currently available data indicate that overall impacts of $\mathrm{OA}$ on commercially important fish stocks in the region will likely be negative.

Many of these findings come from coastal habitats, in which diurnal and seasonal $\mathrm{pH}$ variations can greatly exceed the shifts expected under OA (western Baltic, Saderne et al. 2013; Kattegat, Carstensen et al. 2018). However, the biological effects of such diurnal $\mathrm{pH}$ fluctuations in combination with OA have been investigated rarely (reviewed by Boyd et al. 2016). The only study to test these effects in the Baltic-Skagerrak System investigated responses of the euryhaline barnacle Balanus improvisus (Eriander et al. 2015). This study showed that diurnally fluctuating OA, mimicking future coastal seas, increased variance in growth more than tenfold, revealing strong "winner" and "loser" phenotypes that were not seen in conventional constant OA treatments, and which indicated the potential for adaptation to future OA. Similar differences in responses under constant vs fluctuating OA have been obtained in several other species (Boyd et al. 2016). Collectively, these findings indicate that tolerance to OA in situ may be far more variable than previously thought, and that projecting future impacts of OA from data obtained in experiments using constant OA treatments may be unreliable.

\section{INTERACTIVE EFFECTS OF OCEAN ACIDIFICATION: SPECIES-LEVEL RESPONSES}

OA does not operate in isolation, and interactive and indirect effects (Box 4) are common. Additional drivers such as warming, freshening, and nutrient input are changing simultaneously in the Baltic-Skagerrak System (Meier 2015), leading to concurrent shifts in eutrophication and hypoxia (Conley et al. 2009, 2011), which interact with the effects of OA. Identifying the consequences of these multiple simultaneous drivers is a complex task (Boyd et al. 2018), yet many investigators have begun to address these in the Baltic-Skagerrak System (Table 1). This section focuses on the species-level effects of these interactions. Indirect effects, which operate via the food-web are considered in the following section.

Over the last 150 years, the Baltic has warmed by 0.4-1.5 ${ }^{\circ} \mathrm{C}$ (Gustafsson et al. 2012). Regional climate models project warming in this region will average $+2-3{ }^{\circ} \mathrm{C}$ by the end of this century (Meier 2015). This warming will have substantial direct impacts on marine organisms both independently (e.g. Boyd et al. 2013), and 
Box 4 Direct, indirect, and interactive effects

Anthropogenic drivers (including OA) rarely operate in isolation. Combinations of driver may have additive, synergistic, or antagonistic effects (Todgham and Stillman 2013). Additive effects are linear, and arise when the effects of multiple combined drivers equals the sum of their effects in isolation. In contrast, synergistic and antagonistic effects are non-linear and arise when the combined effects of multiple drivers is greater than (synergistic) or less than (antagonistic) the sum of those drivers in isolation (Todgham and Stillman 2013; Gunderson et al. 2016). Note that, these non-linear terms relate to the outcome of the interaction, not the effect itself: synergistic negative effects of temperature and OA on growth, for example, will create a greater decrease in growth than the sum of their single effects.

Drivers also have direct, and/or indirect, effects on the focal organism or process. Direct effects (of single or multiple drivers) operate directly, such as the impacts of temperature on metabolic rate. Indirect effects operate through chains of interactions, e.g. decreased growth of a filter-feeder due to acidification-induced reduction in nutritional value of its phytoplankton food. Indirect effects typically operate through the food-web, and can be at least as great as direct effects (Alsterberg et al. 2013).

interactively with OA (Doney et al. 2012). Theoretical frameworks for the interaction between warming and acidification are well established (Pörtner and Farrell 2008), and recent work has confirmed this, showing that OA not only reduces the thermal tolerance window, but also can reduce peak performance at optimal temperature (larval cod, Kattegat, Dahlke et al. 2017), and modify intestinal physiology (adult cod, Kattegat, Hu et al. 2016). Other examples show, for example, reduced survival and growth under OA + warming (macroalgae, western Baltic, Al-Janabi et al. 2016b). Surprisingly, however, this pattern is far from uniform, and several investigations have found small, or no, interactive effects of OA + warming (e.g. crustaceans, western Baltic, Pansch et al. 2012; cod, western Baltic, Frommel et al. 2013), or additive effects that averaged the responses seen under each driver independently (e.g. copepods, Gulf of Finland, Vehmaa et al. 2012). Consequently, it is not possible to generalise the biological effects of this interaction (Table 1).

Interactions between $\mathrm{OA}$ and salinity are fundamental to the biogeochemistry of OA in the Baltic-Skagerrak System (Box 2, 3). Climate models project freshening by $\sim 2$ $(\approx 10-20 \%)$ in the Belt-Seas around Denmark, and by $0.5-1(\approx 15-30 \%)$ in the Bothnian Bay by 2100 (Christiansen et al. 2015; Meier 2015). This will drive species distributions further "out" toward the North Sea (Viitasalo et al. 2015). The likely combined biological effects of this freshening with OA in the Baltic-Skagerrak System have received relatively little attention to date. Available data indicate increased sensitivity to OA in low-salinity populations (crustaceans, Gulf of Bothnia, Wood et al. 2016), potential for freshening to counteract the positive effects of
OA on reproductive success (Fucus, Baltic, Serraõ et al. Serrao et al. 1999; Graiff et al. 2017), and no substantive impacts of $\mathrm{OA}+$ freshening on microplankton community structure (Baltic Proper, Wulff et al. 2018; Table 1). This important research area requires further experimental investigation before patterns in responses to this interaction can be identified.

The increased precipitation that is projected to lead to freshening will also flush more inorganic and organic nutrients from land into the Baltic-Skagerrak System. The effects of this nutrient enrichment are well understood: it stimulates planktonic primary production, which contributes to increased sedimentation of organic matter to the sea-floor, where it decomposes, reducing $\mathrm{O}_{2}$ concentrations (creating hypoxia) and simultaneously generating $\mathrm{CO}_{2}$ and acidification (Conley et al. 2011; Meier et al. 2011; Meier 2015; Schneider et al. 2015; Box 3). The effects of hypoxia on marine organisms can be strong, and include behavioural changes, reduced performance, and loss of fitness (Gray et al. 2002), as well as reduced benthic productivity and biodiversity (Weigel et al. 2015). The combined effects of OA and hypoxia are now attracting renewed interest from the scientific community, and recent work in the Baltic-Skagerrak System has shown that OA + hypoxia can cause immune suppression in crustaceans (Skagerrak, Hernroth et al. 2015). Other workers, however, have found no effects of OA + hypoxia (Mytilus, southern Baltic, Jakubowska and Normant 2015), and even strong positive responses have been reported (Macoma, Gulf of Finland, Jansson et al. 2015; Table 1). The long-term prevalence of hypoxia in the Baltic-Skagerrak System (Conley et al. 2011) has almost certainly led to acclimation and adaption in many species, however, the extent to which this has also generated tolerance to $\mathrm{OA}$ is an exciting prospect that remains to be investigated.

\section{INDIRECT EFFECTS OF OCEAN ACIDIFICATION: ECOSYSTEM RESPONSES}

Indirect effects of OA-which operate through shifts in competition and trophic interactions-are common in experiments that expose ecological communities to elevated $\mathrm{pCO}_{2}$. The indirect effects of OA on plankton communities vary among systems, but are typically small and subtle. In bacterioplankton, indirect effects were generally small (Baltic Proper, Lindh et al. 2013; western Baltic, Bergen et al. 2016; Table 1), although one study reported substantial shifts in microbial community composition correlated with shifts in phytoplankton community structure (Gulf of Finland, Hornick et al. 2017). Similar, subtle responses were observed in other studies of OA on community composition of phytoplankton (western Baltic, 
Sommer et al. 2015; Baltic Proper, Paul et al. 2016a, b), although stronger effects were seen in sub-dominant and rare species of phytoplankton (Sommer et al. 2015). These small indirect effects of OA can depend on nutrient availability: when nutrients were not limiting, either through experimental addition or in situ remineralisation, increased $\mathrm{pCO}_{2}$ shifted phytoplankton community composition towards much smaller picophytoplankton (Spitzbergen, Schulz et al. 2013; Kattegat, Bach et al. 2016). This, in turn, indirectly stimulated the microbial loop, which reduced subsequent energy flow to zooplankton and fish (North Sea, Endres et al. 2014; Gulf of Finland, Bermúdez et al. 2016). At an ecosystem level, indirect effects among planktonic species generally lead to small or no effects of OA on community composition (Skagerrak, Horn et al. 2016; Algueró-Muñiz et al. 2017; Langer et al. 2017) and genetic composition (Skagerrak, Langer et al. 2017), although some studies have reported reduced zooplankton biomass (Skagerrak, Taucher et al. 2017), and reduced community respiration (Gulf of Finland, Spilling et al. 2016). Importantly, OA impacts on fatty acid (FA) content of phytoplankton led to radical shifts in FA content, and reduced reproductive output in grazing copepods, indicating the potential for strong OA effects to propagate up the food-web (western Baltic, Rossoll et al. 2012). Field observations of plankton communities also indicate warming-induced shifts toward smaller size composition, with consequent reduction in energy availability to planktivorous fish (Suikkanen et al. 2013). Given that shifts in copepod abundance, size-spectrum, and nutritional quality are likely to cascade to higher trophic levels_-and potentially influence regime shifts between cod-dominated and sprat/herring-dominated states in the Baltic (Casini et al. 2009) - there is a clear need to better understand the consequences of indirect and interactive effects of OA in plankton communities of the Baltic-Skagerrak System.

In benthic ecosystems, indirect effects of OA have been reported to be at least as great as direct effects. For example, mesocosm experiments in the Skagerrak showed OA alone had few or no direct or indirect effects, but the combination of $\mathrm{OA}$ with warming strongly influenced community composition and productivity (Eklöf et al. 2012, 2015; Alsterberg et al. 2013). These results were similar, but not identical, to those seen in response to warming alone (Alsterberg et al. 2013). Indirect trophic effects were also important: warming together with the loss of a keystone consumer strongly promoted the growth of ephemeral algae (Alsterberg et al. 2013), and had additive positive effects on functional diversity of associated fauna (Eklöf et al. 2015), such that overall indirect effects were at least as strong as direct effects (Alsterberg et al. 2013). Dense stands of benthic macrophytes can also generate substantial diurnal and seasonal pH fluctuations (globally, Hofmann et al. 2011; western Baltic, Saderne et al. 2013), which indirectly impact associated flora and fauna. For example, Baltic macroalgal and seagrass communities generate sufficiently large fluctuations in $\mathrm{pH}$ that they can provide temporal refuges from OA stress for calcifying species such as the blue mussel, Mytilus edulis (Wahl et al. 2018). The potential for dense stands of benthic macrophytes to condition the water, and thereby mitigate the impacts of OA throughout the coastal photic zone is clearly considerable (Saderne et al. 2013; Wahl et al. 2018), and warrants further investigation.

Indirect effects of $\mathrm{OA}$ also impact benthic-pelagic coupling, which plays a key ecological role throughout the Baltic-Skagerrak System. Sedimentation of planktonic primary production transfers food-energy to the benthos, which-in sufficiently high quantities-can increase food supply to benthic macrofauna, thereby increasing their resilience to OA (western Baltic, Thomsen and Melzner 2010; Melzner et al. 2011; Thomsen et al. 2013; Pansch et al. 2014; Stapp et al. 2017). However, the observation that $\mathrm{OA}$ reduces the nutritional value of phytoplankton for copepods (western Baltic, Rossoll et al. 2012), indicates that indirect effects of OA in combination with other drivers are likely to negatively influence the food value of particulates reaching benthic filter-feeders. The extent to which this reduction in food quality is offset by any OAinduced increases in total planktonic primary production (Kremp et al. 2012; Eberlein et al. 2017) remains unclear. Benthic macrofauna in the Baltic-Sakgerrak System are nonetheless projected to be negatively impacted by other, non-OA, drivers such as eutrophication, hypoxia, warming, and freshening (Weigel et al. 2015), which may have cascading effects throughout the ecosystem (Bergström et al. 2015; Viitasalo et al. 2015; Vuorinen et al. 2015), potentially driving regime shifts similar to those seen in the pelagic (Casini et al. 2009).

Modelling shows that controlling eutrophication and fishing pressure is central to managing Baltic ecosystemsnot least because responses are non-linear (Niiranen et al. 2013). To date, however, these models have not included direct or indirect effects of OA. In regions where ecosystem management models have included the effects of OA, additive, synergistic, and antagonistic effects of OA with other drivers have been found (e.g. SE Australia, Griffith et al. 2011; US West coast, Kaplan et al. 2010). Including the effects of OA in ecosystem modelling of the BalticSkagerrak System is an important, and currently lacking, step that will permit assessment of ecosystem sensitivity to OA. Doing this calls for: (i) improved empirical knowledge/data on the effects of OA on the physiology and demography of key species, and on ecosystem responses; and (ii) modelling that includes the effects of $\mathrm{OA}$ at 
individual, population, and ecosystem levels (e.g. Koenigstein et al. 2016).

In addition to the drivers discussed above, other anthropogenic drivers have specific interactions with OA that influence the chemistry-and potentially biological responses - of the Baltic-Skagerrak System. Among these, shipping contributes directly to OA through the release not only of $\mathrm{CO}_{2}$ but also of the acidic gases $\mathrm{SO}_{\mathrm{x}}$ and $\mathrm{NO}_{\mathrm{x}}$ (Omstedt et al. 2015), which dissolve in seawater to create sulphuric and nitric acids. Methods to reduce $\mathrm{SO}_{\mathrm{X}}$ emissions to the atmosphere include exhaust-gas scrubber systems that absorb the $\mathrm{SO}_{\mathrm{x}}$ in a counterflow of seawater spray, creating a saline solution of sulphuric acid. Openloop scrubbers that lack effluent treatment systems release this acid direct to surface waters, causing further acidification. Although the effects of such release are small on a basin scale (Turner et al. 2018), in heavily trafficked areas the effects of releasing acidic scrubber effluent on local seawater $\mathrm{pH}$ can be as large as those of anthropogenic ocean acidification (Stips et al. 2016). The biological effects of additional effluent components such as organic microparticles are poorly known.

Warming is also causing marine species distributions to move poleward (so-called "climate tracking"; Pinsky et al. 2013; Hiddink et al. 2015; Molinos et al. 2016). This is projected to increase species turnover (gain of new species, loss of established species) in the coming decades (Molinos et al. 2016). Invasive species are already established throughout the Baltic-Skagerrak System (Hiddink and Coleby 2012; Katsanevakis et al. 2014), with both negative and positive impacts on marine biogeochemistry and ecosystems (reviewed by Katsanevakis et al. 2014) that can interact with OA (Box 3). Although there is strong uncertainty about the timing of further invasions, the establishment of invasive species-especially those tolerant of low $\mathrm{pH}$-seems likely. At the time of writing, no published studies have investigated the effects of OA on warmingdriven range shifts and ecosystem structure and function in the Baltic-Skagerrak System.

\section{THE ROLE OF BIODIVERSITY, EVOLUTION, AND RESILIENCE}

The impacts of $\mathrm{OA}$ and other anthropogenic drivers on marine ecosystems depend not only on the factors and processes considered above. Biodiversity (both genetic variation within species, as well as between species [i.e. richness]), functional diversity (the diversity of ecological functions within an ecosystem), and evolutionary capacity of the component species, are all central to determining the resilience of an ecosystem to disturbance and change
(Doney et al. 2012; Loreau and Mazancourt 2013; Gamfeldt et al. 2015; Lefcheck et al. 2015), and hence to OA.

At a within-species-level, anthropogenic pressures are reducing population sizes and genetic diversity (Harley et al. 2006). In smaller populations, stochastic factors such as genetic drift can restrict the ability of populations to adapt to local conditions (Polechová and Barton 2015). Within-species genetic diversity in the Skagerrak and Kattegat is substantially greater than in populations of the same species in the Baltic (Johannesson and André 2006), and consequently we might expect the adaptive capacity of Baltic populations to $\mathrm{OA}$ to be less than that in the relatively diverse populations of the Skagerrak and Kattegatt. At present, there are no geographically comprehensive data with which we can test this prediction. Nonetheless, it is clear that some Baltic populations are strongly tolerant to extreme levels of OA (e.g. mussels, western Baltic, Thomsen et al. 2017), and that Baltic populations have adapted rapidly in the past to drivers such as salinity change (Pereyra et al. 2009; and see Johannesson et al. 2011). Experimental laboratory work has also shown that Baltic species can adapt rapidly to high $p \mathrm{CO}_{2}$ conditions (e.g. Lohbeck et al. 2012; Stapp et al. 2017). Although the greater complexity of the natural environment may lead to different outcomes (Bach et al. 2018), available evidence nonetheless suggests there is substantial adaptive capacity in Baltic populations.

At the level of ecological communities, loss of species reduces ecosystem functioning, leading to loss of productivity and greater sensitivity to disturbance (Campbell et al. 2011; Cardinale et al. 2012; Worm et al. 2006; Duffy et al. 2016). Thus, biodiversity is critical to the long-term sustainability of ecosystem functions in the face of environmental change (Loreau and Mazancourt, 2013; Oliver et al. 2015). Examples from marine ecosystems include genetic diversity enhancing the resilience of Baltic seagrass beds (Reusch et al. 2005), and species diversity enhancing the resilience of the California Current pelagic ecosystem (Lindegren et al. 2016). The extent to which resilience to $\mathrm{OA}$ is enhanced by biodiversity is less well understood, although work in Swedish seagrass beds indicates that $\mathrm{OA}+$ warming can have positive indirect impacts (Alsterberg et al. 2013), and warming (but not OA) reduces the insurance effect of biodiversity (Eklöf et al. 2012). Conversely, investigations of the effects of $\mathrm{OA}$ on genetic diversity of plankton communities in large mesocosms found no substantive impacts (Skagerrak, Langer et al. 2017). Unfortunately, comparable data from the Baltic Proper are not available. Nonetheless, it seems likely that the reduced biodiversity observed within and among species in the Baltic Sea will decrease ecosystem resilience to $\mathrm{OA}$ and other interacting drivers, rendering the Baltic particularly vulnerable. 


\section{CONSEQUENCES FOR ECOSYSTEM SERVICES}

The impacts of OA on marine ecosystems are likely to have pervasive consequences. The world's coastal oceans, including the Baltic-Skagerrak System, generate numerous ecosystem services that are important for human welfare (Millennium Ecosystem Assessment 2005; TEEB 2010; Hattam et al. 2015). Identifying and forecasting the effects of OA on these services in the Baltic-Skagerrak System is, however, a challenging task for several reasons. First, attributing any given ecosystem change to an individual driver, such as $\mathrm{OA}$, is rarely straightforward because multiple interacting drivers simultaneously cause ecosystem change. Shifts in ecosystem services driven by overfishing, eutrophication, habitat destruction, and OA, for example, have their origins in distal phenomena such as urbanisation, global consumption patterns, trade, etc. (Norström et al. 2017; Österblom et al. 2017). This is exemplified in the Baltic-Skagerrak System by eutrophication-driven ecosystem degradation, which has contributed to declines in marine ecosystem goods and services (Rönnbäck et al. 2007; Österblom et al. 2007). Second, these different impacts often have synergistic (reinforcing) or antagonistic (mitigating) effects on each other (Box 4). Ecosystem disturbances operating over long periods can result in small gradual changes in ecosystem structure and functions, yet can sometimes (and especially when disturbances are strong and synergistic) cause rapid shifts that change ecosystem structure, functions, and services (Scheffer et al. 2001; Österblom et al. 2007; Casini et al. 2009). Conversely, negative impacts on extant fisheries may be offset by positive impacts on new, alternate, fishery species (similar to the effects of ocean warming on fisheries catch, Cheung et al. 2010, but see Cheung et al. 2016), although such trade-offs have yet to be demonstrated for OA. Third, the diversity of ecosystem services implies that OA is likely to affect them in different ways. Among the provisioning ecosystem services alone there are multiple examples, such as the production of fish, which can be impacted by the negative effects of OA on coastal fish species (Baltic herring, Franke and Clemmesen 2011; Kattegatt cod, Stiasny et al. 2016); the negative effects of $\mathrm{OA}$ on aquaculture (e.g. mussel and oyster growth in the USA, Barton et al. 2012); and the possibility of indirect effects of OA on forage fish in distant waters that that are used for aquaculture feeds. Similar OA-driven shifts can also arise in supporting and cultural ecosystem services through impacts on coastal towns reliant on the fishing industry. Finally, people benefiting from these services may value them in very different ways and will be affected differently depending on their own vulnerability and whether or not replacement services exist.
The potential risks for economic losses can be illustrated by looking at just one key provisioning service, the Swedish fishery sector. In 2016, Swedish fisheries were conservatively estimated to be worth $\sim$ SEK 7.5 billion (recreational $=$ SEK 6.2 billion, SCB 2018; industrial $=$ SEK 1.3 billion, HAV 2014), equivalent to $\sim €$ 730 million. Including Swedish aquaculture (SEK 487 million; SCB 2017), pushes this total to $\sim € 780$ million. Of course, not all of this value will be lost as a result of OA impacts (and much aquaculture value is in freshwaters), but as outlined earlier, commercially valuable fish species in the Baltic-Skagerrak System respond negatively to OA, and therefore this key provisioning service could incur substantial financial costs. Currently, however, know too little to make valid quantitative assessments of the likely social and economic risks and vulnerabilities arising from biological responses to OA (Falkenberg and Tubb 2017). In order to make these assessments, we need to meet the relevant requirements (Hilmi et al. 2013): (i) accurate determination of the fraction of GNP that depends on provisioning ecosystem services such as fishing and aquaculture, and cultural services such as coastal tourism, that depend on OA sensitive ecosystems; (ii) identifying likely shifts in species composition, and hence food value, of seafood under OA; (iii) projecting changes in human populations dependent on the coastal zone; (iv) determining the vulnerability and sensitivity of these coastal populations to environmental change and assessing their capacity to adapt.

\section{CONCLUSIONS}

The Baltic-Skagerrak System is characterised by seasonal and diurnal cycles of temperature, primary production, and decomposition, which create strong cycles of $\mathrm{pH}$ variation. Interactions with local biogeochemistry and anthropogenic drivers modify these fluctuations, making the detection of decadal $\mathrm{pH}$ trends from field observations difficult. However, oceanographic models for the Baltic Proper that incorporate the marine carbonate system project increasing seasonal $\mathrm{pH}$ variability and clear long-term (multi-decadal) reductions in mean, and minimum, $\mathrm{pH}$. The results of these models are consistent with projected global trends (Fig. 6; Omstedt et al. 2009, 2012).

The responses of marine organisms in the Baltic-Skagerrak System to levels of ocean acidification (OA) consistent with these trends $\left(\mathrm{pCO}_{2} \leq 1300 \mu \mathrm{atm} ; \mathrm{pH}\right.$ decline $\leq 0.4$ units) vary widely from strongly positive, through neutral, to strongly negative. In general, however, we detected a pattern in which species at higher trophic levels tended respond more negatively to OA. Negative responses to $\mathrm{OA}$ were more common in macrobenthos and 
fish than in plankton. Responses to OA were strongly modified by several factors, most prevalent of which was nutritional status (nutrients for primary producers, food for consumers), such that more nutrients/food led to greater resilience to OA. Investigations of the combined effects of OA with warming, freshening, nutrients, or hypoxia frequently showed strong interactions that overwhelmed (warming), or materially changed (hypoxia), responses in comparison to those seen under OA only. In many instances interactive effects of $\mathrm{OA}+$ other drivers were small or not detected, and responses to other drivers (notably warming) were greater than those to OA.

Responses to OA also vary widely among taxonomic levels: species-level responses were generally stronger (both positive and negative) than responses of communities or ecosystems-indicating the importance of indirect interactions in the ecosystem, which can mediate OA effects on individual taxa. Overall ecosystem (mesocosm) level effects of OA were generally small, although there was evidence for substantial shifts in genetic composition of some plankton communities.

\section{OUTLOOK AND RESEARCH PRIORITIES}

The findings summarised here represent substantial advances in OA research in the Baltic-Skagerrak System in the last 6 years ( $c f$ Havenhand 2012). Nonetheless, our understanding of the interactive and indirect effects of OA remains constrained by our limited knowledge of several key processes, and we know woefully little about how Baltic-Skagerrak species and ecosystems will respond to OA under diurnally, and seasonally, fluctuating cycles (Eriander et al. 2015; Boyd et al. 2016). We echo the sentiments of recent reviews that have emphasised the importance of moving from single drivers, single species, and short timescales, to multiple drivers, ecological communities, and evolutionary responses (e.g. Wernberg et al. 2012; Riebesell and Gattuso 2015; Boyd et al. 2018). In particular, we recommend that future research in the Baltic-Skagerrak System region focus on:

(i) How biogeochemical processes combine to impact the development of OA in brackish coastal seas, and the role of nutrient enrichment and eutrophication; in particular, develop models to project future levels of important drivers under different forcing.

(ii) Quantifying the additive, synergistic (reinforcing), and antagonistic (mediating) responses of keystone, and ecologically dominant, species to OA in combination with other important anthropogenic drivers (notably warming, eutrophication, hypoxia, biodiversity, and fishing). (iii) Determining the extent of phenotypic plasticity and adaptive capacity of key Baltic-Skagerrak species over multiple generations in response to $\mathrm{OA}$, in combination with other important drivers.

(iv) Quantifying the effects of intra- and interspecific biodiversity on ecosystem responses and resilience to $\mathrm{OA}$ in combination with other key drivers; in particular the capacity for OA responses to cascade through the food-web.

(v) Determining the effects of diurnal and seasonal environmental fluctuations, superimposed on $\mathrm{OA}$ and other key drivers, on responses of species and ecosystems

(vi) Developing holistic ecosystem modelling frameworks that incorporate the effects of OA with those of other drivers at large spatial scales

(vii) Evaluating the impacts these processes will have on socially and economically important ecosystem services.

Acknowledgements This work stemmed from a series of workshops on Ocean Acidification sponsored by the Royal Swedish Academy of Sciences. Subsequent workshops, and work by the lead author, was supported by a grant from the Hasselblad Foundation. Earlier versions of the manuscript were improved substantially by comments from Wendy Broadgate, Per Nilsson, and three anonymous referees. We wish to express our gratitude to all. JNH was also supported by a Linnaeus Grant from the Swedish Research Councils VR and FORMAS, to the Centre for Marine Evolutionary Biology (www.cemeb.gu.se). HLF acknowledges funding from the Swedish Research Council FORMAS (Grant No. 210-2012-2140). SN has been supported by the Nordforskfunded project Green Growth Based on Marine Resources: Ecological and Socio-Economic Constraints (GreenMAR). ASC acknowledges funding from the Ebba and Sven Schwartz foundation.

Open Access This article is distributed under the terms of the Creative Commons Attribution 4.0 International License (http:// creativecommons.org/licenses/by/4.0/), which permits unrestricted use, distribution, and reproduction in any medium, provided you give appropriate credit to the original author(s) and the source, provide a link to the Creative Commons license, and indicate if changes were made.

\section{REFERENCES}

Al-Janabi, B., I. Kruse, A. Graiff, U. Karsten, and M. Wahl. 2016a. Genotypic variation influences tolerance to warming and acidification of early life-stage Fucus vesiculosus L. (Phaeophyceae) in a seasonally fluctuating environment. Marine Biology 163: 15.

Al-Janabi, B., I. Kruse, A. Graiff, V. Winde, M. Lenz, and M. Wahl. 2016b. Buffering and amplifying interactions among OAW (ocean acidification and warming) and nutrient enrichment on early life-stage Fucus vesiculosus L. (Phaeophyceae) and their carry over effects to hypoxia impact. PloS ONE 11: e0152948.

Albright, R., L. Caldeira, J. Hosfelt, L. Kwiatkowski, J.K. Maclaren, B.M. Mason, Y. Nebuchina, A. Ninokawa, et al. 2016a. Reversal of ocean acidification enhances net coral reef calcification. Nature 531: 362-365. 
Albright, R., K.R. Anthony, M. Baird, R. Beeden, M. Byrne, C. Collier, S. Dove, K. Fabricius, et al. 2016b. Ocean acidification: Linking science to management solutions using the Great Barrier Reef as a case study. Journal of Environmental Management 182: 641-650.

Algueró-Muñiz, M., C.L. Meunier, S. Holst, S. Alvarez-Fernandez, and M. Boersma. 2016. Withstanding multiple stressors: Ephyrae of the moon jellyfish (Aurelia aurita, Scyphozoa) in a hightemperature, high- $\mathrm{CO}_{2}$ and low-oxygen environment. Marine Biology 163: 185.

Algueró-Muñiz, M., S. Alvarez-Fernandez, P. Thor, L.T. Bach, M. Esposito, H.G. Horn, U. Ecker, J.A.F. Langer, et al. 2017. Ocean acidification effects on mesozooplankton community development: Results from a long-term mesocosm experiment. PLoS ONE 12: 21.

Almén, A.-K., A. Vehmaa, A. Brutemark, L. Bach, S. Lischka, A. Stuhr, S. Furuhagen, A. Paul, et al. 2016. Negligible effects of ocean acidification on Eurytemora affinis (Copepoda) offspring production. Biogeosciences 13: 1037-1048.

Almén, A.K., A. Brutemark, F. Jutfelt, U. Riebesell, and J. EngstromOst. 2017. Ocean acidification causes no detectable effect on swimming activity and body size in a common copepod. Hydrobiologia 802: 235-243.

Alsterberg, C., J.S. Eklof, L. Gamfeldt, J.N. Havenhand, and K. Sundback. 2013. Consumers mediate the effects of experimental ocean acidification and warming on primary producers. Proceedings of the National Academy of Sciences of the USA 110: 8603-8608.

Appelhans, Y.S., J. Thomsen, S. Opitz, C. Pansch, F. Melzner, and M. Wahl. 2014. Juvenile sea stars exposed to acidification decrease feeding and growth with no acclimation potential. Marine Ecology Progress Series 509: 227-239.

Bach, L.T., K.T. Lohbeck, T.B. Reusch, and U. Riebesell. 2018. Rapid evolution of highly variable competitive abilities in a key phytoplankton species. Nature Ecology and Evolution 2: 611.

Bach, L.T., J. Taucher, T. Boxhammer, A. Ludwig, E.P. Achterberg, M. Alguero-Muniz, L.G. Anderson, J. Bellworthy, et al. 2016. Influence of ocean acidification on a natural winter-to-summer plankton succession: First insights from a long-term mesocosm study draw attention to periods of low nutrient concentrations. PLOS ONE 11: e 0159068.

Barton, A., B. Hales, G.G. Waldbusser, C. Langdon, and R.A. Feely. 2012. The Pacific oyster, Crassostrea gigas, shows negative correlation to naturally elevated carbon dioxide levels: Implications for near-term ocean acidification effects. Limnology and Oceanography 57: 698-710.

Bates, N., M. Best, K. Neely, R. Garley, A. Dickson, and R. Johnson. 2012. Detecting anthropogenic carbon dioxide uptake and ocean acidification in the North Atlantic Ocean. Biogeosciences 9: 2509-2522.

Bergen, B., S. Endres, A. Engel, M. Zark, T. Dittmar, U. Sommer, and K. Jurgens. 2016. Acidification and warming affect prominent bacteria in two seasonal phytoplankton bloom mesocosms. Environmental Microbiology 18: 4579-4595.

Bergström, U., J. Olsson, M. Casini, B.K. Eriksson, R. Fredriksson, H. Wennhage, and M. Appelberg. 2015. Stickleback increase in the Baltic Sea: A thorny issue for coastal predatory fish. Estuarine, Coastal and Shelf Science 163: 134-142.

Bermúdez, J.R., U. Riebesell, A. Larsen, and M. Winder. 2016. Ocean acidification reduces transfer of essential biomolecules in a natural plankton community. Scientific Reports 6: 27749.

Bouquet, J.M., C. Troedsson, A. Novac, M. Reeve, A.K. Lechtenborger, W. Massart, K.S. Skaar, A. Aasjord, et al. 2018. Increased fitness of a key appendicularian zooplankton species under warmer, acidified seawater conditions. Plos One 13: 19.
Boyd, P.W., S. Collins, S. Dupont, K. Fabricius, J.P. Gattuso, J. Havenhand, D.A. Hutchins, U. Riebesell, et al. 2018. Experimental strategies to assess the biological ramifications of multiple drivers of global ocean change-A review. Global Change Biology 24: 2239-2261.

Boyd, P.W., C.E. Cornwall, A. Davison, S.C. Doney, M. Fourquez, C.L. Hurd, I.D. Lima, and A. McMinn. 2016. Biological responses to environmental heterogeneity under future ocean conditions. Global Change Biology 22: 2633-2650.

Boyd, P.W., T.A. Rynearson, E.A. Armstrong, F. Fu, K. Hayashi, Z. Hu, D.A. Hutchins, R.M. Kudela, et al. 2013. Marine phytoplankton temperature versus growth responses from polar to tropical waters outcome of a scientific community-wide study. PLOS ONE 8: e63091.

Campbell, V., G. Murphy, and T.N. Romanuk. 2011. Experimental design and the outcome and interpretation of diversity-stability relations. Oikos 120: 399-408.

Cardinale, B.J., J.E. Duffy, A. Gonzalez, D.U. Hooper, C. Perrings, P. Venail, A. Narwani, G.M. Mace, et al. 2012. Biodiversity loss and its impact on humanity. Nature 486: 59-67.

Carey, N., S. Dupont, B. Lundve, and J.D. Sigwart. 2014. One size fits all: Stability of metabolic scaling under warming and ocean acidification in echinoderms. Marine Biology 161: 2131-2142.

Carey, N., S. Dupont, and J.D. Sigwart. 2016. Sea hare Aplysia punctata (Mollusca: Gastropoda) can maintain shell calcification under extreme ocean acidification. Biological Bulletin 231: 142-151.

Carstensen, J., M. Chierici, B.G. Gustafsson, and E. Gustafsson. 2018. Long-term and seasonal trends in estuarine and coastal carbonate systems. Global Biogeochemical Cycles 32: 497-513.

Casini, M., J. Hjelm, J.-C. Molinero, J. Lövgren, M. Cardinale, V. Bartolino, A. Belgrano, and G. Kornilovs. 2009. Trophic cascades promote threshold-like shifts in pelagic marine ecosystems. Proceedings of the National Academy of Sciences of the USA 106: 197-202.

Cheung, W.W., V.W. Lam, J.L. Sarmiento, K. Kearney, R. Watson, D. Zeller, and D. Pauly. 2010. Large-scale redistribution of maximum fisheries catch potential in the global ocean under climate change. Global Change Biology 16: 24-35.

Cheung, W.W., G. Reygondeau, and T.L. Frölicher. 2016. Large benefits to marine fisheries of meeting the $1.5^{\circ} \mathrm{C}$ global warming target. Science 354: 1591-1594.

Christiansen, O.B., E. Kjellström, and E. Zorita. 2015. Projected Change: Atmosphere. In Second assessment of climate change for the Baltic Sea Basin, ed. BACC II Author Team, 245-261. Heidelberg: Springer.

Conley, D.J., S. Björck, E. Bonsdorff, J. Carstensen, G. Destouni, B.G. Gustafsson, S. Hietanen, M. Kortekaas, et al. 2009. Hypoxia-related processes in the Baltic Sea. Environmental Science and Technology 43: 3412-3420.

Conley, D.J., J. Carstensen, J. Aigars, P. Axe, E. Bonsdorff, T. Eremina, B.-M. Haahti, C. Humborg, et al. 2011. Hypoxia is increasing in the coastal zone of the Baltic Sea. Environmental Science and Technology 45: 6777-6783.

Connell, S.D., Z.A. Doubleday, N.R. Foster, S.B. Hamlyn, C.D. Harley, B. Helmuth, B.P. Kelaher, I. Nagelkerken, et al. 2018. The duality of ocean acidification as a resource and a stressor. Ecology 99: 1005-1010.

Crawfurd, K.J., S. Alvarez-Fernandez, K.D.A. Mojica, U. Riebesell, and C.P.D. Brussaard. 2017. Alterations in microbial community composition with increasing $\mathrm{fCO}_{2}$ : A mesocosm study in the eastern Baltic Sea. Biogeosciences 14: 3831-3849.

Czerny, J., J.B.E. Ramos, and U. Riebesell. 2009. Influence of elevated $\mathrm{CO}_{2}$ concentrations on cell division and nitrogen fixation rates in the bloom-forming cyanobacterium Nodularia spumigena. Biogeosciences 6: 1865-1875. 
Dahlke, F.T., E. Leo, F.C. Mark, H.O. Portner, U. Bickmeyer, S. Frickenhaus, and D. Storch. 2017. Effects of ocean acidification increase embryonic sensitivity to thermal extremes in Atlantic cod, Gadus morhua. Global Change Biology 23: 1499-1510.

Doney, S.C., V.J. Fabry, R.A. Feely, and J.A. Kleypas. 2009. Ocean acidification: The other $\mathrm{CO}_{2}$ problem. Annual Review of Marine Science 1: 169-192.

Doney, S.C., M. Ruckelshaus, E. Duffy, J. Barry, F. Chan, C. English, H. Galindo, J. Grebmeier, et al. 2012. Climate change impacts on marine ecosystems. Annual Review of Marine Science 4: 1-27.

Duffy, J.E., J.S. Lefcheck, R.D. Stuart-Smith, S.A. Navarrete, and G.J. Edgar. 2016. Biodiversity enhances reef fish biomass and resistance to climate change. Proceedings of the National Academy of Sciences 113: 6230-6235.

Dupont, S., J. Havenhand, W. Thorndyke, L. Peck, and M. Thorndyke. 2008. Near-future level of $\mathrm{CO}_{2}$-driven ocean acidification radically affects larval survival and development in the brittlestar Ophiothrix fragilis. Marine Ecology-Progress Series 373: 285-294.

Dupont, S., B. Lundve, and M. Thorndyke. 2010. Near future ocean acidification increases growth rate of the lecithotrophic larvae and juveniles of the sea star Crossaster papposus. Journal of Experimental Zoology Part B-Molecular and Developmental Evolution 314B: 382-389.

Dupont, S., N. Dorey, M. Stumpp, F. Melzner, and M. Thorndyke. 2013. Long-term and trans-life-cycle effects of exposure to ocean acidification in the green sea urchin Strongylocentrotus droebachiensis. Marine Biology 160: 1835-1843.

Eberlein, T., S. Wohlrab, B. Rost, U. John, L.T. Bach, U. Riebesell, and D.B. Van de Waal. 2017. Effects of ocean acidification on primary production in a coastal North Sea phytoplankton community. PLOS ONE 12: e0172594.

Eichner, M., B. Rost, and S.A. Kranz. 2014. Diversity of ocean acidification effects on marine $\mathrm{N}_{2}$ fixers. Journal of Experimental Marine Biology and Ecology 457: 199-207.

Eklöf, J., C. Alsterberg, J.N. Havenhand, K. Sundbäck, H. Wood, and L. Gamfeldt. 2012. Experimental climate change weakens the insurance effect of biodiversity. Ecology Letters 15: 864-872.

Eklöf, J.S., J.N. Havenhand, C. Alsterberg, and L. Gamfeldt. 2015. Community-level effects of rapid experimental warming and consumer loss outweigh effects of rapid ocean acidification. Oikos 124: 1040-1049.

Endres, S., L. Galgani, U. Riebesell, K.-G. Schulz, and A. Engel. 2014. Stimulated bacterial growth under elevated $\mathrm{pCO}_{2}$ : Results from an off-shore mesocosm study. PLoS ONE 9: e99228.

Engel, A., J. Piontek, H.P. Grossart, U. Riebesell, K.G. Schulz, and M. Sperling. 2014. Impact of $\mathrm{CO}_{2}$ enrichment on organic matter dynamics during nutrient induced coastal phytoplankton blooms. Journal of Plankton Research 36: 641-657.

Eriander, L., A.-L. Wrange, and J.N. Havenhand. 2015. Simulated diurnal $\mathrm{pH}$ fluctuations radically increase variance in-but not the mean of - growth in the barnacle Balanus improvisus. ICES Journal of Marine Science 73: 596-603.

Falkenberg, L.J., and A. Tubb. 2017. Economic effects of ocean acidification: Publication patterns and directions for future research. Ambio 46: 543-553.

Franke, A., and C. Clemmesen. 2011. Effect of ocean acidification on early life stages of Atlantic herring (Clupea harengus L.). Biogeosciences 8: 3697-3707.

Fehsenfeld, S., R. Kiko, Y. Appelhans, D.W. Towle, M. Zimmer, and F. Melzner. 2011. Effects of elevated seawater $\mathrm{pCO}_{2}$ on gene expression patterns in the gills of the green crab, Carcinus maenas. BMC Genomics 12: 488.

Frommel, A.Y., A. Schubert, U. Piatkowski, and C. Clemmesen. 2013. Egg and early larval stages of Baltic cod, Gadus morhua, are robust to high levels of ocean acidification. Marine Biology 160: $1825-1834$.

Frommel, A.Y., V. Stiebens, C. Clemmesen, and J.N. Havenhand. 2010. Effect of ocean acidification on marine fish sperm (Baltic cod: Gadus morhua). Biogeosciences 7: 3915-3919.

Gamfeldt, L., J.S. Lefcheck, J.E. Byrnes, B.J. Cardinale, J.E. Duffy, and J.N. Griffin. 2015. Marine biodiversity and ecosystem functioning: What's known and what's next? Oikos 124: 252-265.

Gao, K., Y. Zhang, and D.-P. Häder. 2018. Individual and interactive effects of ocean acidification, global warming, and UV radiation on phytoplankton. Journal of Applied Phycology 30: 743-759.

Gattuso, J.-P., and L. Hansson. 2011. Ocean acidification: background and history. In Ocean acidification, ed. J.-P. Gattuso and L. Hansson, 1-20. Oxford: Oxford University Press.

Gattuso, J.-P., A. Magnan, R. Billé, W.W. Cheung, E.L. Howes, F. Joos, D. Allemand, L. Bopp, et al. 2015. Contrasting futures for ocean and society from different anthropogenic $\mathrm{CO}_{2}$ emissions scenarios. Science 349: aac4722.

Glippa, O., J. Engstrom-Ost, M. Kanerva, A. Rein, and K. Vuori. 2018. Oxidative stress and antioxidant defense responses in Acartia copepods in relation to environmental factors. PLoS ONE 13: e195981.

Graiff, A., M. Dankworth, M. Wahl, U. Karsten, and I. Bartsch. 2017. Seasonal variations of Fucus vesiculosus fertility under ocean acidification and warming in the western Baltic Sea. Botanica Marina 60: 239-255.

Gräns, A., F. Jutfelt, E. Sandblom, E. Jönsson, K. Wiklander, H. Seth, C. Olsson, S. Dupont, et al. 2014. Aerobic scope fails to explain the detrimental effects on growth resulting from warming and elevated $\mathrm{CO}_{2}$ in Atlantic halibut. Journal of Experimental Biology 217: 711-717.

Gray, J.S., R.S.-S. Wu, and Y.Y. Or. 2002. Effects of hypoxia and organic enrichment on the coastal marine environment. Marine Ecology Progress Series 238: 249-279.

Griffith, G.P., E.A. Fulton, and A.J. Richardson. 2011. Effects of fishing and acidification-related benthic mortality on the southeast Australian marine ecosystem. Global Change Biology 17: 3058-3074.

Gunderson, A.R., E.J. Armstrong, and J.H. Stillman. 2016. Multiple stressors in a changing world: The need for an improved perspective on physiological responses to the dynamic marine environment. Annual Review of Marine Science 8: 357-378.

Gustafsson, B.G., F. Schenk, T. Blenckner, K. Eilola, H.M. Meier, B. Müller-Karulis, T. Neumann, T. Ruoho-Airola, et al. 2012. Reconstructing the development of Baltic Sea eutrophication 1850-2006. Ambio 41: 534-548.

Harley, C.D.G., A.R. Hughes, K.M. Hultgren, B.G. Miner, C.J.B. Sorte, C.S. Thornber, L.F. Rodriguez, L. Tomanek, et al. 2006. The impacts of climate change in coastal marine systems. Ecology Letters 9: 228-241.

Harnik, P.G., H.K. Lotze, S.C. Anderson, Z.V. Finkel, S. Finnegan, D.R. Lindberg, L.H. Liow, R. Lockwood, et al. 2012. Extinctions in ancient and modern seas. Trends in Ecology and Evolution 27: 608-617.

Harvey, B.P., D. Gwynn-Jones, and P.J. Moore. 2013. Meta-analysis reveals complex marine biological responses to the interactive effects of ocean acidification and warming. Ecology and Evolution 3: 1016-1030.

Hattam, C., J.P. Atkins, N. Beaumont, T. Börger, A. BöhnkeHenrichs, D. Burdon, R. de Groot, E. Hoefnagel, et al. 2015. Marine ecosystem services: linking indicators to their classification. Ecological Indicators 49: 61-75.

HAV. 2014. The balance between the fishing fleet and fishing opportunities. Swedish Agency for Marine and Water Management Report Dnr 1-14 (in Swedish). 
Havenhand, J.N. 2012. How will ocean acidification affect Baltic Sea ecosystems? An assessment of plausible impacts on key functional groups. Ambio 41: 637-644.

Havenhand, J.N., and P. Schlegel. 2009. Near-future levels of ocean acidification do not affect sperm motility and fertilization kinetics in the oyster Crassostrea gigas. Biogeosciences 6: 3009-3015.

Haynert, K., J. Schonfeld, U. Riebesell, and I. Polovodova. 2011. Biometry and dissolution features of the benthic foraminifer Ammonia aomoriensis at high $\mathrm{pCO}_{2}$. Marine Ecology Progress Series 432: 53-67.

Hernroth, B., S. Baden, M. Thorndyke, and S. Dupont. 2011. Immune suppression of the echinoderm Asterias rubens (L.) following long-term ocean acidification. Aquatic Toxicology 103: 222-224.

Hernroth, B., A.S. Krång, and S. Baden. 2015. Bacteriostatic suppression in Norway lobster (Nephrops norvegicus) exposed to manganese or hypoxia under pressure of ocean acidification. Aquatic Toxicology 159: 217-224.

Hernroth, B., H.N. Sköld, K. Wiklander, F. Jutfelt, and S. Baden. 2012. Simulated climate change causes immune suppression and protein damage in the crustacean Nephrops norvegicus. Fish and Shellfish Immunology 33: 1095-1101.

Hiddink, J.G., M.T. Burrows, and J.G. Molinos. 2015. Temperature tracking by North Sea benthic invertebrates in response to climate change. Global Change Biology 21: 117-129.

Hiddink, J.G., and C. Coleby. 2012. What is the effect of climate change on marine fish biodiversity in an area of low connectivity, the Baltic Sea? Global Ecology and Biogeography 21: 637-646.

Hiebenthal, C., E.E.R. Philipp, A. Eisenhauer, and M. Wahl. 2013. Effects of seawater $\mathrm{pCO}_{2}$ and temperature on shell growth, shell stability, condition and cellular stress of Western Baltic Sea Mytilus edulis (L.) and Arctica islandica (L.). Marine Biology 160: 2073-2087.

Hilmi, N., D. Allemand, S. Dupont, A. Safa, G. Haraldsson, P.A. Nunes, C. Moore, C. Hattam, et al. 2013. Towards improved socio-economic assessments of ocean acidification's impacts. Marine Biology 160: 1773-1787.

Hjalmarsson, S., K. Wesslander, L.G. Anderson, A. Omstedt, M. Perttilä, and L. Mintrop. 2008. Distribution, long-term development and mass balance calculation of total alkalinity in the Baltic Sea. Continental Shelf Research 28: 593-601.

Hofmann, G.E., J.E. Smith, K.S. Johnson, U. Send, L.A. Levin, F. Micheli, A. Paytan, N.N. Price, et al. 2011. High-frequency dynamics of ocean $\mathrm{pH}$ : A multi-ecosystem comparison. PLoS ONE 6: e28983.

Holtmann, W.C., M. Stumpp, M.A. Gutowska, S. Syre, N. Himmerkus, F. Melzner, and M. Bleich. 2013. Maintenance of coelomic fluid $\mathrm{pH}$ in sea urchins exposed to elevated $\mathrm{CO}_{2}$ : The role of body cavity epithelia and stereom dissolution. Marine Biology 160: 2631-2645.

Horn, H.G., N. Sander, A. Stuhr, M. Alguero-Muniz, L.T. Bach, M.G.J. Loder, M. Boersma, U. Riebesell, et al. 2016. Low $\mathrm{CO}_{2}$ sensitivity of microzooplankton communities in the Gullmar Fjord, Skagerrak: Evidence from a long-term mesocosm study. PLOS ONE 11: 24.

Hornick, T., L.T. Bach, K.J. Crawfurd, K. Spilling, E.P. Achterberg, J.N. Woodhouse, K.G. Schulz, C.P.D. Brussaard, et al. 2017. Ocean acidification impacts bacteria-phytoplankton coupling at low-nutrient conditions. Biogeosciences 14: 1-15.

Hönisch, B., and N.G. Hemming. 2005. Surface ocean pH response to variations in $\mathrm{pCO}_{2}$ through two full glacial cycles. Earth and Planetary Science Letters 236: 305-314.

Hönisch, B., A. Ridgwell, D.N. Schmidt, E. Thomas, S.J. Gibbs, A. Sluijs, R. Zeebe, L. Kump, et al. 2012. The geological record of ocean acidification. Science 335: 1058-1063.
Hu, M.Y., I. Casties, M. Stumpp, O. Ortega-Martinez, and S. Dupont. 2014. Energy metabolism and regeneration are impaired by seawater acidification in the infaunal brittlestar Amphiura filiformis. Journal of Experimental Biology 217: 2411-2421.

$\mathrm{Hu}$, M.Y., K. Michael, C.M. Kreiss, M. Stumpp, S. Dupont, Y.C. Tseng, and M. Lucassen. 2016. Temperature modulates the effects of ocean acidification on intestinal ion transport in Atlantic cod, Gadus morhua. Frontiers in Physiology 7: 18.

$\mathrm{Hu}$, M.Y., E. Lein, M. Bleich, F. Melzner, and M. Stumpp. 2018. Trans-life cycle acclimation to experimental ocean acidification affects gastric $\mathrm{pH}$ homeostasis and larval recruitment in the sea star Asterias rubens. Acta Physiologica 224: e13075.

Hüning, A., F. Melzner, J. Thomsen, M.A. Gutowska, L. Kramer, S. Frickenhaus, P. Rosenstiel, H.O. Portner, et al. 2013. Impacts of seawater acidification on mantle gene expression patterns of the Baltic Sea blue mussel: implications for shell formation and energy metabolism. Marine Biology 160: 1845-1861.

Jagers, S.C., S. Matti, A.-S. Crépin, D. Langlet, J.N. Havenhand, M. Troell, H.L. Filipsson, V.R. Galaz, et al. 2018. Societal causes of, and responses to, ocean acidification. Ambio. https://doi.org/ 10.1007/s13280-018-1103-2.

Jakubowska, M., M. Jerzak, M. Normant, D. Burska, and J. Drzazgowski. 2013. Effect of carbon dioxide-induced water acidification on the physiological processes of the baltic isopod Saduria entomon. Journal of Shellish Research 32: 825-834.

Jakubowska, M., and M. Normant. 2015. Metabolic rate and activity of blue mussel Mytilus edulis trossulus under short-term exposure to carbon dioxide-induced water acidification and oxygen deficiency. Marine and Freshwater Behaviour and Physiology 48: 25-39.

Jakubowska, M., and M. Normant-Saremba. 2015. The effect of $\mathrm{CO}_{2-}$ induced seawater acidification on the behaviour and metabolic rate of the Baltic clam Macoma balthica. Annales Zoologici Fennici 52: 353-367.

Jansson, A., S. Lischka, T. Boxhammer, K.G. Schulz, and J. Norkko. 2016. Survival and settling of larval Macoma balthica in a largescale mesocosm experiment at different fCO2 levels. Biogeosciences 13: 3377-3385.

Jansson, A., J. Norkko, S. Dupont, and A. Norkko. 2015. Growth and survival in a changing environment: combined effects of moderate hypoxia and low $\mathrm{pH}$ on juvenile bivalve Macoma balthica. Journal of Sea Research 102: 41-47.

Jansson, A., J. Norkko, and A. Norkko. 2013. Effects of reduced pH on Macoma balthica larvae from a system with naturally fluctuating pH-dynamics. PLOS ONE 8: e68198.

Johannesson, K., and C. Andre. 2006. Life on the margin: Genetic isolation and diversity loss in a peripheral marine ecosystem, the Baltic Sea. Molecular Ecology 15: 2013-2029.

Johannesson, K., K. Smolarz, M. Grahn, and C. Andre. 2011. The future of Baltic Sea Populations: Local extinction or evolutionary rescue? Ambio 40: 179-190.

Jutfelt, F., and M. Hedgarde. 2013. Atlantic cod actively avoid $\mathrm{CO}_{2}$ and predator odour, even after long-term $\mathrm{CO}_{2}$ exposure. Frontiers in Zoology 10: 7.

Kaplan, I.C., P.S. Levin, M. Burden, and E.A. Fulton. 2010. Fishing catch shares in the face of global change: A framework for integrating cumulative impacts and single species management. Canadian Journal of Fisheries and Aquatic Sciences 67: 1968-1982.

Katsanevakis, S., I. Wallentinus, A. Zenetos, E. Leppäkowski, B. Oztürk, M. Grabowski, D. Golani, and A. Cardoso. 2014. Impacts of invasive alien marine species on ecosystem services and biodiversity: A pan-European review. Aquatic Invasions 9: 391-423.

Koenigstein, S., F.C. Mark, S. Gößling-Reisemann, H. Reuter, and H.O. Poertner. 2016. Modelling climate change impacts on 
marine fish populations: Process-based integration of ocean warming, acidification and other environmental drivers. Fish and Fisheries 17: 972-1004.

Kremp, A., A. Godhe, J. Egardt, S. Dupont, S. Suikkanen, S. Casabianca, and A. Penna. 2012. Intraspecific variability in the response of bloom-forming marine microalgae to changed climate conditions. Ecology and Evolution 2: 1195-1207.

Kroeker, K.J., R.L. Kordas, R. Crim, I.E. Hendriks, L. Ramajo, G.S. Singh, C.M. Duarte, and J.P. Gattuso. 2013. Impacts of ocean acidification on marine organisms: Quantifying sensitivities and interaction with warming. Global Change Biology 19: 1884-1896.

Kroeker, K.J., R.L. Kordas, and C.D. Harley. 2017. Embracing interactions in ocean acidification research: Confronting multiple stressor scenarios and context dependence. Biology Letters 13: 20160802.

Langer, G., G. Nehrke, I. Probert, J. Ly, and P. Ziveri. 2009. Strainspecific responses of Emiliania huxleyi to changing seawater carbonate chemistry. Biogeosciences 6: 2637-2646.

Langer, J.A.F., R. Sharma, S.I. Schmidt, S. Bahrdt, H.G. Horn, M. Alguero-Muniz, B. Nam, E.P. Achterberg, et al. 2017. Community barcoding reveals little effect of ocean acidification on the composition of coastal plankton communities: Evidence from a long-term mesocosm study in the Gullmar Fjord, Skagerrak. Plos One 12: 20.

Lefcheck, J.S., J.E. Byrnes, F. Isbell, L. Gamfeldt, J.N. Griffin, N. Eisenhauer, M.J. Hensel, A. Hector, et al. 2015. Biodiversity enhances ecosystem multifunctionality across trophic levels and habitats. Nature Communications 6: 6936.

Lemasson, A.J., S. Fletcher, J.M. Hall-Spencer, and A.M. Knights. 2017. Linking the biological impacts of ocean acidification on oysters to changes in ecosystem services: A review. Journal of Experimental Marine Biology and Ecology 492: 49-62.

Lindegren, M., D.M. Checkley, M.D. Ohman, J.A. Koslow, and R. Goericke. 2016. Resilience and stability of a pelagic marine ecosystem. Proceedings of the Royal Society B-Biological Sciences 283: 9.

Lindh, M.V., L. Riemann, F. Baltar, C. Romero-Oliva, P.S. Salomon, E. Graneli, and J. Pinhassi. 2013. Consequences of increased temperature and acidification on bacterioplankton community composition during a mesocosm spring bloom in the Baltic Sea. Environmental Microbiology Reports 5: 252-262.

Lischka, S., L.T. Bach, K.-G. Schulz, and U. Riebesell. 2017. Ciliate and mesozooplankton community response to increasing $\mathrm{CO}_{2}$ levels in the Baltic Sea: Insights from a large-scale mesocosm experiment. Biogeosciences 14: 447-466.

Lohbeck, K.T., U. Riebesell, and T.B.H. Reusch. 2012. Adaptive evolution of a key phytoplankton species to ocean acidification. Nature Geosciences 5: 346-351.

Loreau, M., and C. Mazancourt. 2013. Biodiversity and ecosystem stability: A synthesis of underlying mechanisms. Ecology Letters 16: $106-115$.

Mammitzsch, K., G. Jost, and K. Jurgens. 2014. Impact of dissolved inorganic carbon concentrations and $\mathrm{pH}$ on growth of the chemolithoautotrophic epsilonproteobacterium Sulfurimonas gotlandica GD1(T). Microbiology Open 3: 80-88.

Meier, H.E.M., H.C. Andersson, K. Eilola, B.G. Gustafsson, I. Kuznetsov, B. Müller-Karulis, T. Neumann, and O.P. Savchuk. 2011. Hypoxia in future climates: A model ensemble study for the Baltic Sea. Geophysical Research Letters 38: 24.

Meier, M. 2015. Projected change: Marine physics. In Second assessment of climate change for the Baltic Sea basin, ed. BACC II Author Team, 243-252. Heidelberg: Springer.

Melzner, F., S. Gobel, M. Langenbuch, M.A. Gutowska, H.O. Portner, and M. Lucassen. 2009. Swimming performance in Atlantic cod (Gadus morhua) following long-term
(4-12 months) acclimation to elevated seawater $\mathrm{P}\left(\mathrm{CO}_{2}\right)$. Aquatic Toxicology 92: 30-37.

Melzner, F., P. Stange, K. Trubenbach, J. Thomsen, I. Casties, U. Panknin, S.N. Gorb, and M.A. Gutowska. 2011. Food supply and seawater $\mathrm{pCO}_{2}$ impact calcification and internal shell dissolution in the blue mussel Mytilus edulis. PLoS ONE 6: e24223.

Meyer, J., and U. Riebesell. 2015. Responses of coccolithophores to ocean acidification: A meta-analysis. Biogeosciences 12: $1671-1682$.

Michael, K., C.M. Kreiss, M.Y. Hu, N. Koschnick, U. Bickmeyer, S. Dupont, H.O. Portner, and M. Lucassen. 2016. Adjustments of molecular key components of branchial ion and $\mathrm{pH}$ regulation in Atlantic cod (Gadus morhua) in response to ocean acidification and warming. Comparative Biochemistry and Physiology B-Biochemistry and Molecular Biology 193: 33-46.

Millennium Ecosystem Assessment. 2005. Ecosystems and human well-being: Biodiversity synthesis. Washington, DC: Island Press.

Molinos, J.G., B.S. Halpern, D.S. Schoeman, C.J. Brown, W. Kiessling, P.J. Moore, J.M. Pandolfi, E.S. Poloczanska, et al. 2016. Climate velocity and the future global redistribution of marine biodiversity. Nature Climate Change 6: 83.

Mostofa, K.M., C.-Q. Liu, W. Zhai, M. Minella, D. Vione, K. Gao, D. Minakata, T. Arakaki, et al. 2016. Reviews and Syntheses: Ocean acidification and its potential impacts on marine ecosystems. Biogeosciences 13: 1767-1786.

Müller, J.D., B. Schneider, and G. Rehder. 2016. Long-term alkalinity trends in the Baltic Sea and their implications for $\mathrm{CO}_{2}$-induced acidification. Limnology and Oceanography 61: 1984-2002.

Ni, S., I. Taubner, F. Bohm, V. Winde, and M.E. Bottcher. 2018. Effect of temperature rise and ocean acidification on growth of calcifying tubeworm shells (Spirorbis spirorbis): An in situ benthocosm approach. Biogeosciences 15: 1425-1445.

Niiranen, S., J. Yletyinen, M.T. Tomczak, T. Blenckner, O. Hjerne, B.R. MacKenzie, B. Müller-Karulis, T. Neumann, et al. 2013. Combined effects of global climate change and regional ecosystem drivers on an exploited marine food web. Global Change Biology 19: 3327-3342.

Näslund, J., E. Lindström, F. Lai, and F. Jutfelt. 2015. Behavioural responses to simulated bird attacks in marine three-spined sticklebacks after exposure to high $\mathrm{CO}_{2}$ levels. Marine and Freshwater Research 66: 877-885.

Norström, A.V., P. Balvanera, M.J. Spierenburg, and M. Bouamrane. 2017. Programme on ecosystem change and society: Knowledge for sustainable stewardship of social-ecological systems. Ecology and Society 22: 47.

Oesterwind, D., A. Rau, and A. Zaiko. 2016. Drivers and pressuresuntangling the terms commonly used in marine science and policy. Journal of Environmental Management 181: 8-15.

Oliver, T.H., M.S. Heard, N.J. Isaac, D.B. Roy, D. Procter, F. Eigenbrod, R. Freckleton, A. Hector, et al. 2015. Biodiversity and resilience of ecosystem functions. Trends in Ecology \& Evolution 30: 673-684.

Olsson, J., L. Bergström, and A. Gårdmark. 2012. Abiotic drivers of coastal fish community change during four decades in the Baltic Sea. ICES Journal of Marine Science 69: 961-970.

Olsson, J., M.T. Tomczak, H. Ojaveer, A. Gårdmark, A. Põllumäe, B. Müller-Karulis, D. Ustups, G.E. Dinesen, et al. 2015. Temporal development of coastal ecosystems in the Baltic Sea over the past two decades. ICES Journal of Marine Science 72: 2539-2548.

Omstedt, A., M. Edman, B. Claremar, P. Frodin, E. Gustafsson, C. Humborg, H. Hägg, M. Mörth, et al. 2012. Future changes in the Baltic Sea acid-base $(\mathrm{pH})$ and oxygen balances. Tellus $B$ 64: 19586. 
Omstedt, A., M. Edman, B. Claremar, and A. Rutgersson. 2015. Modelling the contributions to marine acidification from deposited $\mathrm{SO}_{\mathrm{x}}, \mathrm{NO}_{\mathrm{x}}$, and $\mathrm{NH}_{\mathrm{x}}$ in the Baltic Sea: Past and present situations. Continental Shelf Research 111: 234-249.

Omstedt, A., E. Gustafsson, and K. Wesslander. 2009. Modelling the uptake and release of carbon dioxide in the Baltic Sea surface water. Continental Shelf Research 29: 870-885.

Österblom, H., B.I. Crona, C. Folke, M. Nyström, and M. Troell. 2017. Marine ecosystem science on an intertwined planet. Ecosystems 20: 54-61.

Österblom, H., S. Hansson, U. Larsson, O. Hjerne, F. Wulff, R. Elmgren, and C. Folke. 2007. Human-induced trophic cascades and ecological regime shifts in the Baltic sea. Ecosystems 10: $877-889$.

Pajusalu, L., G. Martin, and A. Pollumae. 2013. Results of laboratory and field experiments of the direct effect of increasing $\mathrm{CO}_{2}$ on net primary production of macroalgal species in brackish-water ecosystems. Proceedings of the Estonian Academy of Sciences 62: $148-154$.

Pansch, C., G.S.I. Hattich, M.E. Heinrichs, A. Pansch, Z. Zagrodzka, and J.N. Havenhand. 2018. Long-term exposure to acidification disrupts reproduction in a marine invertebrate. PLOS ONE 13: 17.

Pansch, C., A. Nasrolahi, Y.S. Appelhans, and M. Wahl. 2012. Impacts of ocean warming and acidification on the larval development of the barnacle Amphibalanus improvisus. Journal of Experimental Marine Biology and Ecology 420: 48-55.

Pansch, C., P. Schlegel, and J. Havenhand. 2013. Larval development of the barnacle Amphibalanus improvisus responds variably but robustly to near-future ocean acidification. ICES Journal of Marine Science 70: 805-811.

Pansch, C., I. Schaub, J. Havenhand, and M. Wahl. 2014. Habitat traits and food availability determine the response of marine invertebrates to ocean acidification. Global Change Biology 20: 765-777.

Paul, A.J., E.P. Achterberg, L.T. Bach, T. Boxhammer, J. Czerny, M. Haunost, K.G. Schulz, A. Stuhr, et al. 2016a. No observed effect of ocean acidification on nitrogen biogeochemistry in a summer Baltic Sea plankton community. Biogeosciences 13: 3901-3913.

Paul, C., U. Sommer, J. Garzke, M. Moustaka-Gouni, A. Paul, and B. Matthiessen. 2016b. Effects of increased $\mathrm{CO}_{2}$ concentration on nutrient limited coastal summer plankton depend on temperature. Limnology and Oceanography 61: 853-868.

Pereyra, R.T., L. Bergström, L. Kautsky, and K. Johannesson. 2009. Rapid speciation in a newly opened postglacial marine environment, the Baltic Sea. BMC Evolutionary Biology 9: 70.

Pinsky, M.L., B. Worm, M.J. Fogarty, J.L. Sarmiento, and S.A. Levin. 2013. Marine taxa track local climate velocities. Science 341: $1239-1242$.

Polechová, J., and N.H. Barton. 2015. Limits to adaptation along environmental gradients. Proceedings of the National Academy of Sciences of the USA 112: 6401-6406.

Pörtner, H.O., and A.P. Farrell. 2008. Physiology and climate change. Science 322: 690-692.

Raddatz, S., T. Guy-Haim, G. Rilov, and M. Wahl. 2017. Future warming and acidification effects on anti-fouling and antiherbivory traits of the brown alga Fucus vesiculosus (Phaeophyceae). Journal of Phycology 53: 44-58.

Repolho, T., B. Duarte, G. Dionisio, J.R. Paula, A.R. Lopes, I.C. Rosa, T.F. Grilo, I. Cacador, et al. 2017. Seagrass ecophysiological performance under ocean warming and acidification. Scientific Reports 7: 41443.

Reusch, T.B.H., A. Ehlers, A. Hammerli, and B. Worm. 2005. Ecosystem recovery after climatic extremes enhanced by genotypic diversity. Proceedings of the National Academy of Sciences of the USA 102: 2826-2831.
Riebesell, U., and J.-P. Gattuso. 2015. Lessons learned from ocean acidification research. Nature Climate Change 5: 12-14.

Rönnbäck, P., N. Kautsky, L. Pihl, M. Troell, T. Söderqvist, and H. Wennhage. 2007. Ecosystem goods and services from Swedish coastal habitats: Identification, valuation, and implications of ecosystem shifts. Ambio 36: 534-544.

Rossoll, D., R. Bermúdez, H. Hauss, K.G. Schulz, U. Riebesell, U. Sommer, and M. Winder. 2012. Ocean acidification-induced food quality deterioration constrains trophic transfer. PLOS ONE 7: e34737.

Saderne, V., P. Fietzek, and P.M.J. Herman. 2013. Extreme variations of $\mathrm{pCO}_{2}$ and $\mathrm{pH}$ in a macrophyte meadow of the Baltic Sea in summer: Evidence of the effect of photosynthesis and local upwelling. PLoS ONE 8: e62689.

Saderne, V., and M. Wahl. 2013. Differential responses of calcifying and non-calcifying epibionts of a brown macroalga to presentday and future upwelling $\mathrm{pCO}_{2}$. PLOS ONE 8: e70455.

SCB. 2017. Aquaculture in Sweden in 2016. Swedish Central Bureau of Statistics, Report JO 60 SM 1701, Stockholm, Sweden (in Swedish, English summary).

SCB. 2018. Recreational fishing in Sweden 2016. Swedish Central Bureau of Statistics, Report JO 57 SM 1801, Stockholm, Sweden (in Swedish, English summary).

Schade, F.M., C. Clemmesen, and K.M. Wegner. 2014. Within-and transgenerational effects of ocean acidification on life history of marine three-spined stickleback (Gasterosteus aculeatus). Marine Biology 161: 1667-1676.

Scheffer, M., S. Carpenter, J.A. Foley, C. Folke, and B. Walker. 2001. Catastrophic shifts in ecosystems. Nature 413: 591-596.

Schneider, B., K. Eilola, K. Lukkari, B. Müller-Karulis. and T. Neumann. 2015. Environmental impacts- marine biogeochemistry. In Second assessment of climate change for the Baltic Sea basin, ed. BACC II Author Team, 337-362. Heidelberg: Springer.

Schulz, K.G., R. Bellerby, C.P. Brussaard, J. Büdenbender, J. Czerny, A. Engel, M. Fischer, S. Koch-Klavsen, et al. 2013. Temporal biomass dynamics of an Arctic plankton bloom in response to increasing levels of atmospheric carbon dioxide. Biogeosciences 10: $161-180$.

Serrao, E.A., S.H. Brawley, J. Hedman, L. Kautsky, and G. Samuelson. 1999. Reproductive success of Fucus vesiculosus (Phaeophyceae) in the Baltic Sea. Journal of Phycology 35: 254-269.

Sokolowski, A., D. Brulinska, Z. Mirny, D. Burska, and D. Pryputniewicz-Flis. 2018. Differing responses of the estuarine bivalve Limecola balthica to lowered water $\mathrm{pH}$ caused by potential $\mathrm{CO}_{2}$ leaks from a sub-seabed storage site in the Baltic Sea: An experimental study. Marine Pollution Bulletin 127: 761-773.

Sommer, U., C. Paul, and M. Moustaka-Gouni. 2015. Warming and ocean acidification effects on phytoplankton -from species shifts to size shifts within species in a mesocosm experiment. PLoS ONE 10: e125239.

Spilling, K., A.J. Paul, N. Virkkala, T. Hastings, S. Lischka, A. Stuhr, R. Bermúdez, J. Czerny, et al. 2016. Ocean acidification decreases plankton respiration: Evidence from a mesocosm experiment. Biogeosciences 13: 4707-4719.

Stapp, L.S., J. Thomsen, H. Schade, C. Bock, F. Melzner, H.O. Portner, and G. Lannig. 2017. Intra-population variability of ocean acidification impacts on the physiology of Baltic blue mussels (Mytilus edulis): Integrating tissue and organism response. Journal of Comparative Physiology B 187: 529-543.

Steffen, W., K. Richardson, J. Rockström, S.E. Cornell, I. Fetzer, E.M. Bennett, R. Biggs, S.R. Carpenter, et al. 2015. Planetary boundaries: Guiding human development on a changing planet. Science 347: 1259855. 
Stemmer, K., G. Nehrke, and T. Brey. 2013. Elevated $\mathrm{CO}_{2}$ levels do not affect the shell structure of the bivalve Arctica islandica from the western Baltic. PLoS ONE 8: e70106.

Stiasny, M.H., F.H. Mittermayer, M. Sswat, R. Voss, F. Jutfelt, M. Chierici, V. Puvanendran, A. Mortensen, et al. 2016. Ocean acidification effects on Atlantic cod larval survival and recruitment to the fished population. PLOS ONE 11: e0155448.

Stips, A., K. Bolding, D. Macias, J. Bruggeman, and C. Coughlan. 2016. Scoping report on the potential impact of on-board desulphurisation on water quality in $\mathrm{SO}_{\mathrm{x}}$ emission control areas. EUR 27886. https://doi.org/10.2788/336630.

Stumpp, M., S. Dupont, M.C. Thorndyke, and F. Melzner. 2011a. $\mathrm{CO}_{2}$ induced seawater acidification impacts sea urchin larval development II: Gene expression patterns in pluteus larvae. Comparative Biochemistry and Physiology A-Molecular and Integrative Physiology 160: 320-330.

Stumpp, M., J. Wren, F. Melzner, M.C. Thorndyke, and S.T. Dupont. 2011b. $\mathrm{CO}_{2}$ induced seawater acidification impacts sea urchin larval development I: Elevated metabolic rates decrease scope for growth and induce developmental delay. Comparative Biochemistry and Physiology A-Molecular and Integrative Physiology 160: 331-340.

Stumpp, M., M. Hu, I. Casties, R. Saborowski, M. Bleich, F. Melzner, and S. Dupont. 2013. Digestion in sea urchin larvae impaired under ocean acidification. Nature Climate Change 3: 1044-1049.

Stumpp, M., K. Trubenbach, D. Brennecke, M.Y. Hu, and F. Melzner. 2012. Resource allocation and extracellular acid-base status in the sea urchin Strongylocentrotus droebachiensis in response to $\mathrm{CO}_{2}$ induced seawater acidification. Aquatic Toxicology 110: 194-207.

Suikkanen, S., S. Pulina, J. Engström-Öst, M. Lehtiniemi, S. Lehtinen, and A. Brutemark. 2013. Climate change and eutrophication induced shifts in northern summer plankton communities. PLoS ONE 8: e66475.

Sundin, J., and F. Jutfelt. 2016. 9-28 d of exposure to elevated $\mathrm{pCO}_{2}$ reduces avoidance of predator odour but had no effect on behavioural lateralization or swimming activity in a temperate wrasse (Ctenolabrus rupestris). ICES Journal of Marine Science 73: 620-632.

Takolander, A., M. Cabeza, and E. Leskinen. 2017. Climate change can cause complex responses in Baltic Sea macroalgae: A systematic review. Journal of Sea Research 123: 16-29.

Taucher, J., M. Haunost, T. Boxhammer, L.T. Bach, M. AlgueroMuniz, and U. Riebesell. 2017. Influence of ocean acidification on plankton community structure during a winter-to-summer succession: An imaging approach indicates that copepods can benefit from elevated $\mathrm{CO}_{2}$ via indirect food web effects. PLoS ONE 12: 23.

TEEB. 2010. The economics of ecosystems and biodiversity: Mainstreaming the economics of nature: A synthesis of the approach, conclusions and recommendations of TEEB. Brussels: UNEPEU.

Thomsen, J., I. Casties, C. Pansch, A. Kortzinger, and F. Melzner. 2013. Food availability outweighs ocean acidification effects in juvenile Mytilus edulis: Laboratory and field experiments. Global Change Biology 19: 1017-1027.

Thomsen, J., and F. Melzner. 2010. Moderate seawater acidification does not elicit long-term metabolic depression in the blue mussel Mytilus edulis. Marine Biology 157: 2667-2676.

Thomsen, J., L.S. Stapp, K. Haynert, H. Schade, M. Danelli, G. Lannig, K.M. Wegner, and F. Melzner. 2017. Naturally acidified habitat selects for ocean acidification-tolerant mussels. Science Advances 3: e1602411.

Thor, P., and S. Dupont. 2015. Transgenerational effects alleviate severe fecundity loss during ocean acidification in a ubiquitous planktonic copepod. Global Change Biology 21: 2261-2271.
Thor, P., and E.O. Oliva. 2015. Ocean acidification elicits different energetic responses in an Arctic and a boreal population of the copepod Pseudocalanus acuspes. Marine Biology 162: 799807.

Todgham, A.E., and J.H. Stillman. 2013. Physiological responses to shifts in multiple environmental stressors: Relevance in a changing world. Integrative and Comparative Biology 53: 539-544.

Torda, G., J.M. Donelson, M. Aranda, D.J. Barshis, L. Bay, M.L. Berumen, D.G. Bourne, N. Cantin, et al. 2017. Rapid adaptive responses to climate change in corals. Nature Climate Change 7: 627.

Turner, D.R., M. Edman, J.A. Gallego-Urrea, B. Claremar, I.M. Hassellov, A. Omstedt, and A. Rutgersson. 2018. The potential future contribution of shipping to acidification of the Baltic Sea. Ambio 47: 368-378.

Ulfsbo, A., S. Hulth, and L.G. Anderson. 2011. pH and biogeochemical processes in the Gotland Basin of the Baltic Sea. Marine Chemistry 127: 20-30.

van Vuuren, D.P., J. Edmonds, M. Kainuma, K. Riahi, A. Thomson, K. Hibbard, G.C. Hurtt, T. Kram, et al. 2011. The representative concentration pathways: An overview. Climatic Change 109: 5.

Van Colen, C., A. Jansson, A. Saunier, T. Lacoue-Labathe, and M. Vincx. 2018. Biogeographic vulnerability to ocean acidification and warming in a marine bivalve. Marine Pollution Bulletin 126: 308-311.

Vehmaa, A., A.-K. Almén, A. Brutemark, A.J. Paul, U. Riebesell, S. Furuhagen, and J. Engström-Öst. 2016. Ocean acidification challenges copepod reproductive plasticity. Biogeosciences 13: 6171-6182.

Vehmaa, A., A. Brutemark, and J. Engstrom-Ost. 2012. Maternal effects may act as an adaptation mechanism for copepods facing $\mathrm{pH}$ and temperature changes. PLOS ONE 7: 8.

Ventura, A., S. Schulz, and S. Dupont. 2016. Maintained larval growth in mussel larvae exposed to acidified under-saturated seawater. Scientific Reports 6: 23728.

Viitasalo, M., T. Blenckner, A. Gårdmark, H. Kaartokallio, L. Kautsky, H. Kuosa, M. Lindegren, A. Norkko, et al. 2015. Environmental impacts-marine ecosystems. In Second assessment of climate change for the Baltic Sea basin, ed. BACC II Author Team, 363-380. Heidelberg: Springer.

Vuorinen, I., J. Hänninen, M. Rajasilta, P. Laine, J. Eklund, F. Montesino-Pouzols, F. Corona, K. Junker, et al. 2015. Scenario simulations of future salinity and ecological consequences in the Baltic Sea and adjacent North Sea areas-implications for environmental monitoring. Ecological Indicators 50: 196205.

Wahl, M., S. Schneider Covachã, V. Saderne, C. Hiebenthal, J. Müller, C. Pansch, and Y. Sawall. 2018. Macroalgae may mitigate ocean acidification effects on mussel calcification by increasing $\mathrm{pH}$ and its fluctuations. Limnology and Oceanography 63: 3-21.

Wallace, R.B., H. Baumann, J.S. Grear, R.C. Aller, and C.J. Gobler. 2014. Coastal ocean acidification: The other eutrophication problem. Estuarine, Coastal and Shelf Science 148: 1-13.

Weigel, B., H.C. Andersson, H.E.M. Meier, T. Blenckner, M. Snickars, and E. Bonsdorff. 2015. Long-term progression and drivers of coastal zoobenthos in a changing system. Marine Ecology Progress Series 528: 141-159.

Wernberg, T., D.A. Smale, and M.S. Thomsen. 2012. A decade of climate change experiments on marine organisms: Procedures, patterns and problems. Global Change Biology 18: 1491-1498.

Werner, F.J., A. Graiff, and B. Matthiessen. 2016. Temperature effects on seaweed-sustaining top-down control vary with season. Oecologia 180: 889-901. 
Wikner, J., and A. Andersson. 2012. Increased freshwater discharge shifts the trophic balance in the coastal zone of the northern Baltic Sea. Global Change Biology 18: 2509-2519.

Winder, M., J.M. Bouquet, J. Rafael Bermúdez, S.A. Berger, T. Hansen, J. Brandes, A.F. Sazhin, J.C. Nejstgaard, et al. 2017. Increased appendicularian zooplankton alter carbon cycling under warmer more acidified ocean conditions. Limnology and Oceanography 62: 1541-1551.

Wood, H.L., H.N. Skold, and S.P. Eriksson. 2014. Health and population-dependent effects of ocean acidification on the marine isopod Idotea balthica. Marine Biology 161: 2423-2431.

Wood, H.L., K. Sundell, B.C. Almroth, H.N. Skold, and S.P. Eriksson. 2016. Population-dependent effects of ocean acidification. Proceedings of the Royal Society B-Biological Sciences 283: 7.

Worm, B., E.B. Barbier, N. Beaumont, J.E. Duffy, C. Folke, B.S. Halpern, J.B.C. Jackson, H.K. Lotze, et al. 2006. Impacts of biodiversity loss on ocean ecosystem services. Science 314: 787-790.

Wulff, A., M. Karlberg, M. Olofsson, A. Torstensson, L. Riemann, F.S. Steinhoff, M. Mohlin, N. Ekstrand, et al. 2018. Ocean acidification and desalination: Climate-driven change in a Baltic Sea summer microplanktonic community. Marine Biology 165: 63.

Zeebe, R.E., A. Ridgwell, and J.C. Zachos. 2016. Anthropogenic carbon release rate unprecedented during the past 66 million years. Nature Geosciences 9: 325-329.

Zhao, L., S. Milano, E.O. Walliser, and B.R. Schone. 2018. Bivalve shell formation in a naturally $\mathrm{CO}_{2}$-enriched habitat: Unraveling the resilience mechanisms from elemental signatures. Chemosphere 203: 132-138.

\section{AUTHOR BIOGRAPHIES}

Jonathan N. Havenhand $(\bowtie)$ is a senior researcher in the Department of Marine Sciences at the University of Gothenburg, Sweden. $\mathrm{He}$ is based at the Tjärnö Marine Laboratory, where he works on reproductive ecology and adaptations of marine organisms to rapid environmental change. In recent years his research has focussed on the impacts of ocean global change, especially the effects of ocean acidification on marine organisms and ecosystems.

Address: Department of Marine Sciences, Tjärnö Marine Laboratory, University of Gothenburg, Strömstad, 45296 Gothenburg, Sweden. e-mail: jon.havenhand@marine.gu.se

Helena L. Filipsson is Professor of Quaternary Geology, with a focus on marine geology, at Lund University, Sweden. Her research interests include past and present marine environments and their relation to climate and climate change foremost over the last 130000 years. She is particularly interested in coastal environments subjected to low oxygen conditions and human impact, and proxy development, i.e. improving the tools used to reconstruct past marine environments. Address: Department of Geology, Lund University, 22362 Lund, Sweden.

e-mail: helena.filipsson@geol.lu.se

Susa Niiranen is a marine ecologist. Her research is focussed on marine food-web dynamics and she uses ecosystem modelling as her main research tool. She is also interested in social-ecological interactions in marine systems.

Address: Stockholm Resilience Centre, Stockholm University, Kräftriket 2B, 10691 Stockholm, Sweden.

e-mail: susa.niiranen@su.se
Max Troell is an Associate Professor and senior researcher at the Beijer Institute of Ecological Economics where he leads the programme on sustainable seafood. He is also leading research on global food systems and multifunctional land and seascapes at Stockholm Resilience Centre.

Address: Stockholm Resilience Centre, Stockholm University, Kräftriket 2B, 10691 Stockholm, Sweden.

Address: Beijer Institute of Ecological Economics, Royal Swedish Academy of Science, Lilla Frescativägen 4, 10405 Stockholm, Sweden.

e-mail: max@beijer.kva.se

Anne-Sophie Crépin is an Associate Professor and the Deputy Director of the Beijer Institute of Ecological Economics at the Royal Swedish Academy of Sciences. She holds a PhD in economics from Stockholm University and is also a member of the strategic advisory board at the Stockholm Resilience Centre at Stockholm University. Her research interests include the complex links between biosphere and economic dynamics with focus on regime shifts, sustainability and resilience.

Address: Beijer Institute of Ecological Economics, Royal Swedish Academy of Science, Lilla Frescativägen 4, 10405 Stockholm, Sweden.

e-mail: annesophie.crepin@beijer.kva.se

Sverker Jagers is a Professor in Political Science and Director of the Centre for Collective Action Research (CeCAR) at the University of Gothenburg. His research interests include survey and experimental studies of environmental public opinion and drivers of pro-environmental behaviour and country-comparative time-series analyses of environmental performance.

Address: Department of Political Sciences, University of Gothenburg, Box 711, Sprängkullsgatan 19, 40530 Gothenburg, Sweden. e-mail: sverker.jagers@pol.gu.se

David Langlet holds the newly established chair in Ocean Governance Law at the School of Business, Economics and Law, University of Gothenburg. His research focuses primarily on the dynamics of multi-level regulation of ocean-related activities.

Address: Department of Law, University of Gothenburg, Box 650, 40530 Gothenburg, Sweden.

e-mail: david.langlet@law.gu.se

Simon Matti is Associate Professor of Political Science at Luleå University of Technology, and a senior researcher at the Centre for Collective Action Research, University of Gothenburg. His main research interests concern the intersect between public policy and public opinion in the environmental and natural resource management field.

Address: Department of Political Sciences, Luleå University of Technology, 97187 Luleå, Sweden.

e-mail: simon.matti@ltu.se

David Turner is Professor Emeritus of Marine Chemistry at the University of Gothenburg. His research interests include the development and application of chemical models for seawater, the development of accurate measurement methods for $\mathrm{pH}$ in low-salinity seawater, and understanding the consequences of smokestack emissions from shipping for the marine environment.

Address: Department of Marine Sciences, University of Gothenburg, Box 461, 40530 Gothenburg, Sweden.

e-mail: david.turner@marine.gu.se 
Monika Winder is a Professor in Marine Ecology at Stockhom University with particular interests in the causes and consequences of environmental change for food-web interactions and ecosystem functioning. Her research addresses questions in lakes, estuarinecoastal, and ocean ecosystems with a special emphasis on planktonic organisms.

Address: Department of Ecology, Environment and Plant Sciences, Stockholm University, 10691 Stockholm, Sweden.

e-mail: monika.winder@su.se

Pierre de Wit is a postdoctoral research fellow in the Department of Marine Sciences at the University of Gothenburg. He has a background in evolutionary biology and molecular ecology, and his current research focuses on the genomics of stress adaptation in marine invertebrates.

Address: Department of Marine Sciences, Tjärnö Marine Laboratory, University of Gothenburg, Strömstad, 45296 Gothenburg, Sweden. e-mail: pierre.de_wit@marine.gu.se

Leif G. Anderson is Professor Emeritus in Marine Chemistry at the University of Gothenburg. His research interest centres on the ocean carbon cycle with a focus on its role in the climate system.

Address: Department of Marine Sciences, University of Gothenburg, Box 461, 40530 Gothenburg, Sweden.

e-mail: leif.anderson@marine.gu.se 